\title{
The Extensive Parameters as a Tool to Monitoring the Volcanic Activity: The Case Study of Vulcano Island (Italy)
}

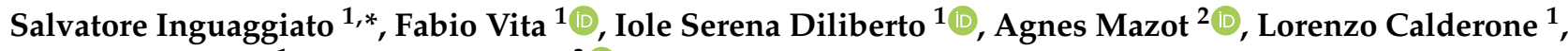 \\ Andrea Mastrolia ${ }^{1}$ and Marco Corrao ${ }^{3}$ (D) \\ 1 Istituto Nazionale di Geofisica e Vulcanologia, Sezione di Palermo, Palermo Via Ugo La Malfa, \\ 90146 Palermo, Italy; fabio.vita@ingv.it (F.V.); iole.diliberto@ingv.it (I.S.D.); \\ lorenzo.calderone@ingv.it (L.C.); andrea.mastrolia@ingv.it (A.M.) \\ 2 GNS Science Wairakei Research Centre, Wairakei, 114 Karetoto Road, Taupo Private Bag 2000, \\ Taupo 3352, New Zealand; a.mazot@gns.cri.nz \\ 3 Geologist, Capo d'Orlando (Me) 98071, Italy; corrao@conteco.it \\ * Correspondence: salvatore.inguaggiato@ingv.it; Tel.: +39-091-6809-435
}

check for

updates

Citation: Inguaggiato, S.; Vita, F.;

Diliberto, I.S.; Mazot, A.; Calderone,

L.; Mastrolia, A.; Corrao, M. The

Extensive Parameters as a Tool to

Monitoring the Volcanic Activity:

The Case Study of Vulcano Island

(Italy). Remote Sens. 2022, 14, 1283.

https://doi.org/10.3390/rs14051283

Academic Editors: Zhong Lu

and David Gomez-Ortiz

Received: 18 January 2022

Accepted: 1 March 2022

Published: 5 March 2022

Publisher's Note: MDPI stays neutral with regard to jurisdictional claims in published maps and institutional affiliations.

Copyright: (C) 2022 by the authors. Licensee MDPI, Basel, Switzerland. This article is an open access article distributed under the terms and conditions of the Creative Commons Attribution (CC BY) license (https:// creativecommons.org/licenses/by/ $4.0 /)$.

\begin{abstract}
On Vulcano Island (Italy), many geochemical crises have occurred during the last 130 years of solfataric activity. The main crises occurred in 1978-1980, 1988-1991, 1996, 2004-2007, 2009-2010 and the ongoing 2021 anomalous degassing activity. These crises have been characterized by early signals of resuming degassing activity, measurable by the increase of volatiles and energy output emitted from the summit areas of the active cone, and particularly by increases of gas/water ratios in the fumarolic area at the summit. In any case, a direct rather than linear correspondence has been observed among the observed increase in the fluid output, seismic release and ground deformation, and is still a subject of study. We present here the results obtained by the long-term monitoring (over 13 years of observations) of three extensive parameters: the $\mathrm{SO}_{2}$ flux monitored in the volcanic plume, the soil $\mathrm{CO}_{2}$ flux and the local heat flux, monitored in the mild thermal anomaly located to the east of the high-temperature fumarole. The time variations of these parameters showed cyclicity in the volcanic degassing and a general increase in the trend in the last period. In particular, we focused on the changes in the mass and energy output registered in the period of June-December 2021, to offer in near-real-time the first evaluation of the level and duration of the actual exhalative crisis affecting Vulcano Island. In this last event, a clear change in degassing style was recorded for the volatiles emitted by the magma. For example, the flux of diffused $\mathrm{CO}_{2}$ from the soils reached the maximum never-before-recorded value of $34,000 \mathrm{~g} \mathrm{~m}^{-2} \mathrm{~d}^{-1}$ and the flux of $\mathrm{SO}_{2}$ of the plume emitted by the fumarolic field on the summit crater area reached values higher than $200 \mathrm{t} \mathrm{d}^{-1}$. The interpretation of the behavior of this volcanic system, resulting from the detailed analyses of these continuous monitoring data, will complete the framework of observations and help in defining and possibly forecasting the next evolution of the actual exhaling crisis.
\end{abstract}

Keywords: $\mathrm{SO}_{2}$ flux; $\mathrm{CO}_{2}$ flux; heat flux; Vulcano Island; geochemical crisis; extensive parameters

\section{Introduction}

Volatiles degassing from volcanic systems is a peculiar and useful tool for monitoring the volcanic activity by characterizing the geochemistry of shallow plumbing systems, and by highlighting the changes of the volcanic outgassing in order to forecast the next evolution of the system.

Many scientists have carried out investigations to identify the main active degassing structures that are present on volcanic systems by means of the volatile degassing reaching the shallow hydrothermal plumbing systems, either dissolved in groundwater, bubbling out of surface water, outpoured by the ground as diffuse degassing or released through fumaroles and volcanic plume [1]. 
The fluid phase expanding towards the surface to respond to the physical and chemical gradients allow for the tracking and interpreting of the energy and mass exchange between the magmatic source, the shallow plumbing system and the atmosphere.

Many volcano observatories have been established throughout the world, and the network of observable phenomena include some geochemical parameters selected among the extensive and intensive variables.

The extensive parameters, like $\mathrm{CO}_{2}, \mathrm{SO}_{2}$ and heat fluxes from soil and plume, can be monitored continuously by remote sensing, thanks to the technological evolution that refined the optical instruments and to the active research, verified and constrained by the direct measurements (and continuous monitoring) of spy parameters carried out in some select locations.

Such a geochemical tool has been successfully applied to Vulcano Island, the southernmost of the islands of the Aeolian archipelago, characterized by solfataric activity in the last few centuries after the last eruption occurred in 1888-1890 [2-12]. The solfataric activity is mainly concentrated in the top part of the island in the crater of the Fossa and the Bay of Levante (Figure 1). Furthermore, anomalous diffuse degassing from the soils is present in the Palizzi area and in part of the inhabited center of Vulcano.

Vulcano Island Geochemical Network

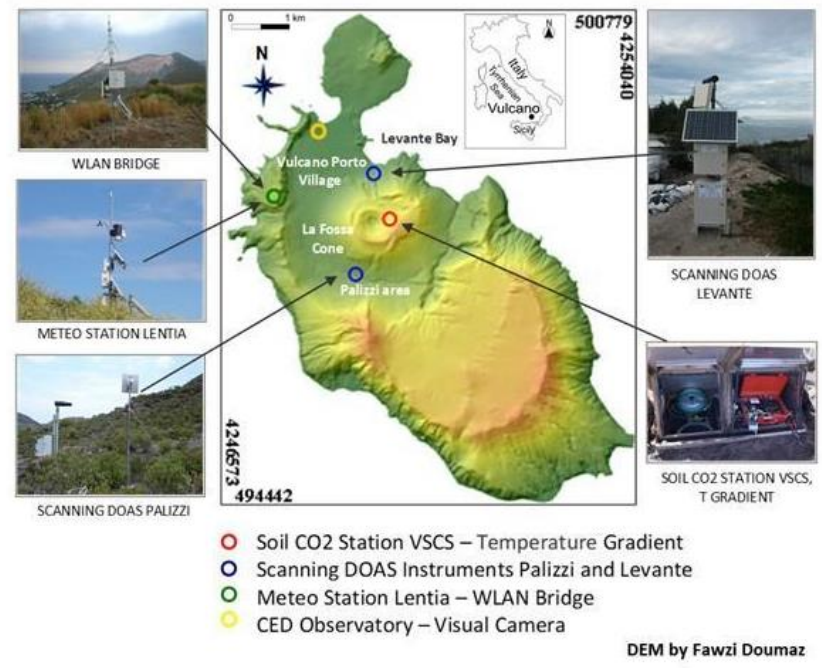

Figure 1. Location map of monitoring stations supplying the discussed datasets with pictures of each measurement system: W-LAN bridge; scanning DOAS Levante and Palizzi for $\mathrm{SO}_{2}$ plume flux monitoring; VSCS station for $\mathrm{CO}_{2}$ diffuse flux and temperature monitoring.; Meteo station Lentia.

During the last 130 years of observed normal solfataric activity, many geochemical crises occurred and were recognized. In particular, these crises have been characterized by clear signals of resuming degassing activity with increases of volatiles and energy output emitted from summit areas of Vulcano Island and by increases of gas/water ratio of the main high-temperature fumaroles located in the La Fossa Crater. The main crises observed occurred in 1978-1980 [13], 1988-1991 [14-18], 1996 [19], 2004-2007 [20-22], 2009-2010 [5,7] and the ongoing 2021 anomalous degassing activity.

Many other studies, carried out in different volcanic areas, already highlighted that the diffuse degassing of $\mathrm{CO}_{2}$ and the associated thermal output cannot be considered a negligible component in the energy and mass balance of solfataric activity [1,23-31].

Moreover, many different geochemical investigations were carried out to estimate the $\mathrm{CO}_{2}$ output of discharged fluids from Vulcano Island $[3,6,32,33]$. It was also discovered that the summit area accounts for more than $90 \%$ of total $\mathrm{CO}_{2}$ discharged from the island [6] and is a suitable site for installing a geochemical monitoring station to investigate volcanic activity. Therefore, an automated soil $\mathrm{CO}_{2}$ fluxes monitoring station was installed in 
September 2007 within the active summit crater of La Fossa, beyond the fumarolic areas [5] to investigate, in near-real-time, any changes in the level of solfataric activity.

Other investigations about the energy output diffused from the soils have been carried out by $[20,34]$ that introduced the theoretical background for the evaluation and monitoring of diffuse thermal release. Such areas have been defined as steam-heated soils (SHS), or sub-fumaroles, and are worthy of attention in the scientific investigations of volcanic activity because they can highlight the turning condition from background and anomalous exhaling activity by monitoring the volcanic activity at a safe distance from the main conduits [35-40].

The best site for monitoring the changes in the heat release from a volcanic system is where the condensation zone is just below the monitored profile because the simple temperature measurements in the ground track the vertical shifts of the massive convective front and the correlated changes in the diffuse heat flux. Figure 2 shows a schematic section of the steam-heated soil in the sub-fumaroles zone. In the same Figure, on the left is the linear temperature distribution within the shallow ground, accounting for the diffusive heat transfer.

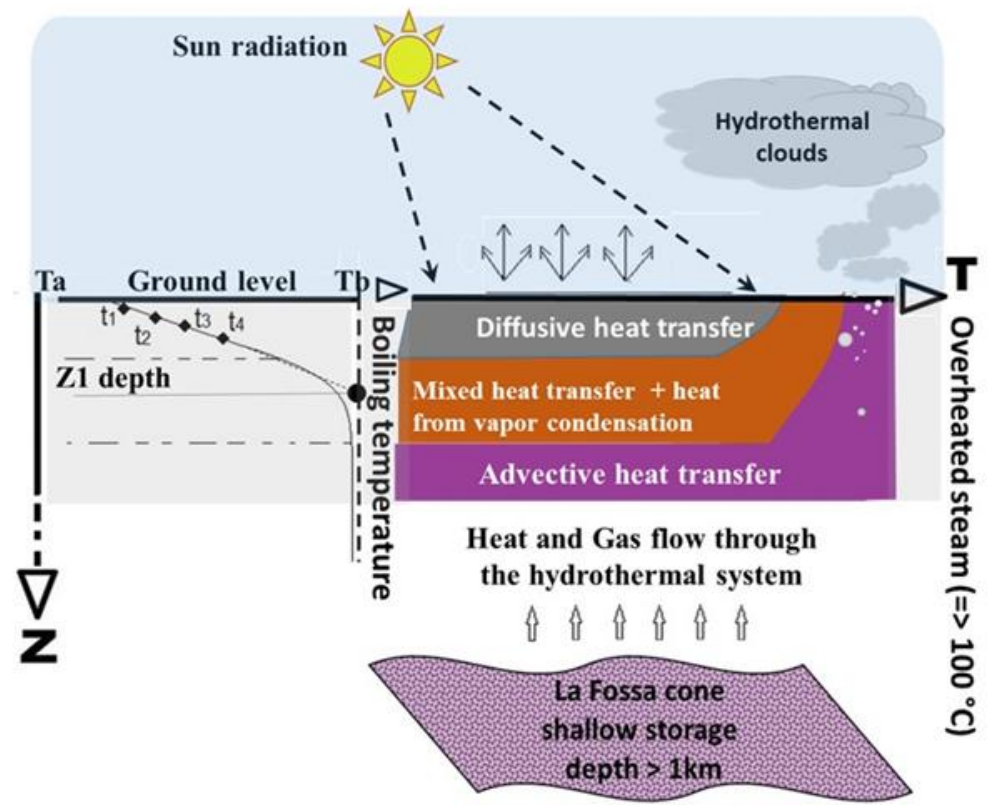

Figure 2. Schematic section of the steam-heated soil in the sub-fumaroles zone. In the same Figure, on the left is the linear temperature distribution within the shallow ground, accounting for the diffusive heat transfer.

Consequently, the three continuous monitoring parameters considered in this investigation are the $\mathrm{SO}_{2}$ flux evaluated in the volcanic plume, the diffuse $\mathrm{CO}_{2}$ flux and the heat flux emitted from the soil in the summit area of La Fossa crater (Figure 1; $[6,7,20]$ ).

This article aims to present the obtained results on the long-term monitoring (over 13 years of observations) of these three extensive parameters, showing changes in the mass and energy output useful to evaluate in real-time the degassing activity level of this volcanic system. Moreover, we analyzed in detail the last strong ongoing degassing that occurred in Vulcano Island in the period June-December 2021, in order to show the evolution of the actual exhaling crisis.

\section{Geological and Volcanological Background}

Vulcano Island is one of the most active volcanoes of the Tyrrhenian Sea, the exposed summit of a volcanic edifice sited in the southern-most sector of the Aeolian archipelago (Figure 3). The Aeolian Archipelago is part of a volcanic arc located in a complex geodynamic setting. The complexity of this regional sector in the southern Tyrrenium sea is due to three different tectonically active areas resulting from the Neogene-Quaternary Africa-Eurasia convergence with extension zones oriented NE-SW and NNW-SSE in west 
Calabria and NE Sicily, respectively, an E-W oriented belt of compression affecting the southern Tyrrhenian Sea above western and central Sicily and the NNW-SSE trending rightlateral Aeolian-Tindari-Letojanni fault system in between [40-44] (Ruch. J. et al., 2016; Pecerillo et al., 2006, 2013; De Astis 2013; Neri et al., 2005; D’Agostino and Selvaggi, 2004). The whole volcanic edifice forming the island of Vulcano rises from the local sea floor (about $1000 \mathrm{~m}$ b.s.l.) up to the maximum height of $499 \mathrm{~m}$ a.s.l. at Monte Aria [43-47]. The Island consists of overlapping volcanic edifices whose formation began at $120 \mathrm{ka}[43,48,49]$. The volcanic system comprises the Primordial Vulcano edifice (120-100 ka), dissected by the development of Il Piano caldera that lasted until around $100 \mathrm{ka}$ before the present and subsequently by the La Fossa caldera (dating back from 80 to $15 \mathrm{ka}$ before the present) [48-50]. In the last $15 \mathrm{ka}$, new eruptive vents were activated in the northern sector of the island, developing in a N-S direction. The two most recent volcanic structures are the La Fossa cone, the active volcanic center developing the stratocone that started to erupt around 5.5 ka b.p. [51], and Vulcanello, the small volcanic peninsula in the northern part of La Fossa caldera. The Vulcanello peninsula, showing three coalescent crater rims, is composed of a lava platform and three partially overlapping scoria cones aligned NE-SW along the northern ring fault of La Fossa caldera [52].

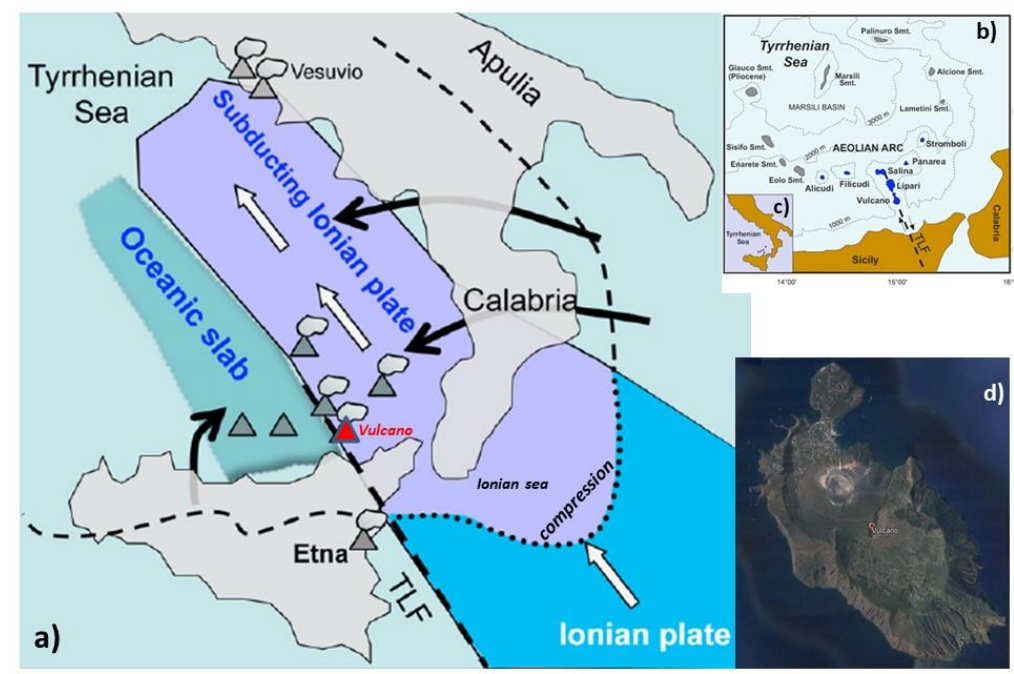

Figure 3. (a) Geodynamic setting; (b) Aeolian Archipelago sketch map; (c) South Italy map, modified from Peccerillo et al. 2013; (d) Vulcano Island image from Google Earth.

The presence of a magmatic chamber below the La Fossa cone is required to account for the time variations of diffuse degassing registered in the area and the whole volcanic edifice forming the island of Vulcano rises from the local sea floor (about $1000 \mathrm{~m}$ b.s.l.) up to the maximum height of $499 \mathrm{~m}$ a.s.l. at Monte Aria [45]. The Island consists of overlapping volcanic edifices whose formation began at $120 \mathrm{ka}[43,48,49]$. The volcanic system comprises the Primordial Vulcano edifice (120-100 ka), dissected by the development of Il Piano caldera that lasted until around $100 \mathrm{ka}$ before the present and subsequently by the La Fossa caldera (dating back from 80 to $15 \mathrm{ka}$ before the present [48,50]. In the last $15 \mathrm{ka}$, new eruptive vents were activated in the northern sector of the island, developing in a $\mathrm{N}-\mathrm{S}$ direction. The two most recent volcanic structures are the La Fossa cone, the active volcanic center developing the stratocone that started to erupt around $5.5 \mathrm{ka} \mathrm{b.p.,} \mathrm{[51]} \mathrm{and}$ Vulcanello, the small volcanic peninsula in the northern part of La Fossa caldera. The Vulcanello peninsula, showing three coalescent crater rims, is composed of a lava platform and three partially overlapping scoria cones aligned NE-SW along the northern ring fault of La Fossa caldera [52]. The presence of a magmatic chamber below the La Fossa cone is required to account for the time variations of diffuse degassing registered in the area and is also suggested by the high geothermal gradients measured in the Agip boreholes [53]. Different geophysical and geochemical evidence accounts for the evaluated depths of 
magma storage. These two different approaches agree with indicating a multibaric and multi-thermal plumbing system during the entire life of Vulcano, and in identifying the different magma storages at about $20 \mathrm{~km}$ of depth at $13-8 \mathrm{~km}$ and $5-3 \mathrm{~km}$, as well as the shallowest storage system zone, indicatively located about 1-2 km beneath the La Fossa cone [42]. The magmatic intrusion located 1-2 km of depth, and the magmatic storage at about 5-3 km, have been strongly influencing the shallow hydrothermal system, feeding the fumarolic field of the Grancratere of La Fossa, during the historical observation period.

\section{Materials and Methods}

\subsection{Plume $\mathrm{SO}_{2}$ Fluxes, Network and Methodology of the UV Scanning DOAS Network on Vulcano Island}

The remote sensing technique of passive DOAS (differential optical absorption spectroscopy), [54,55] allows the quantifying of different volcanic gases within the columns emitted from active volcanoes by collecting the spectra in the ultraviolet region (UV) in order to supply indirect measurements of magmatic volatiles [7,56-58]. The DOAS method is based on the principles of absorption spectroscopy (Bouger-Beer-Lambert law) and is used for the quantification of different trace gases' concentrations (e.g., $\mathrm{SO}_{2}, \mathrm{NO}_{2}, \mathrm{BrO}$ ).

In the framework of the "Network for Observation of Volcanic and Atmospheric Change" (NOVAC), a worldwide network of permanent scanning DOAS instruments was installed on 19 volcanoes around the world, to measure in real-time the emitting $\mathrm{SO}_{2}$ fluxes for volcanic gas monitoring [59]. The NOVAC network was established with a project funded by the European Union in the period 2005-2010, thereafter, it continued to be maintained and expanded, thanks to resources supplied from the volcano observatories initially involved in the active project. The NOVAC community currently counts about 160 stations on 47 volcanoes in different regions of the world, now including Iceland, Philippines, Indonesia, Papua New Guinea and Montserrat [60]. The present work shows the updated results of the ground-based scanning DOAS network installed at Vulcano Island Italy in 2008 (Figures 1 and 4). The results presented here are the first example of $\mathrm{SO}_{2}$ continuous monitoring, performed in a closed conduit volcano with solfataric activities and relatively low gas emissions, like the active cone of Vulcano Island. On the active cone of Vulcano Island, these long-term measurements of $\mathrm{SO}_{2}$ flux have provided relevant information about the reference level of volcanic activity; they would contribute to evaluating the number of volcanic gases released into the atmosphere by this natural source. In 2015, the monitoring network had been implemented, thanks to the Vulcamed project, with the installation of a new UV-scanning DOAS station on the NW side of the island. This implemented configuration allowed the tracking of plumes for more than $80 \%$ of days during each solar cycle (one year). All the data acquired from each measurement station are telemetered in real-time to reference the Vulcano Observatory (in this case to the local INGV volcanological center Carapezza) through a wireless system. From the Vulcano Observatory, the data are transmitted via the internet in near-real-time to the Istituto Nazionale di Geofisica e Vulcanologia (INGV, Palermo); moreover, both the raw and the analyzed data have been hosted in Gothenburg and mirrored in Brussels and Heidelberg [61].

The NOVAC scanning DOAS instruments provide a direct method for measuring the total $\mathrm{SO}_{2}$ flux from Vulcano Island and for sharing data with a worldwide scientific community involved in geophysical and environmental research. Details of the instrument and operation routines are described in $[59,60,62]$. The system consists of a single spectrometer from the Ocean Optics Company (S2000 spectrograph), an embedded personal computer, a global positioning system receiver, a timer, an optical fiber and a telescope.

The spectrometer used (S2000 from the Ocean Optics Company) a 2400 lines/mm grating combined with a $50 \mathrm{~nm}$ slit, which provided an optical resolution of ca. $0.6 \mathrm{~nm}$ over a wavelength range of $280 \mathrm{~nm}$ to $390 \mathrm{~nm}$.

The telescope automatically moves from horizon to horizon using a stepper motor. The control unit is running on a Linux operating system and includes a serial, USB 2 and 
Ethernet communication ports. Serial ports are used for communication with the spectrometer and control of the scanner's stepper motor. The USB port can be used for powering the spectrometer, while the Ethernet port is usually used for data transfer to radio modems. A digital thermometer allows the recording of the internal temperature, a voltmeter checks the battery voltage and a GPS antenna records the position and working time.
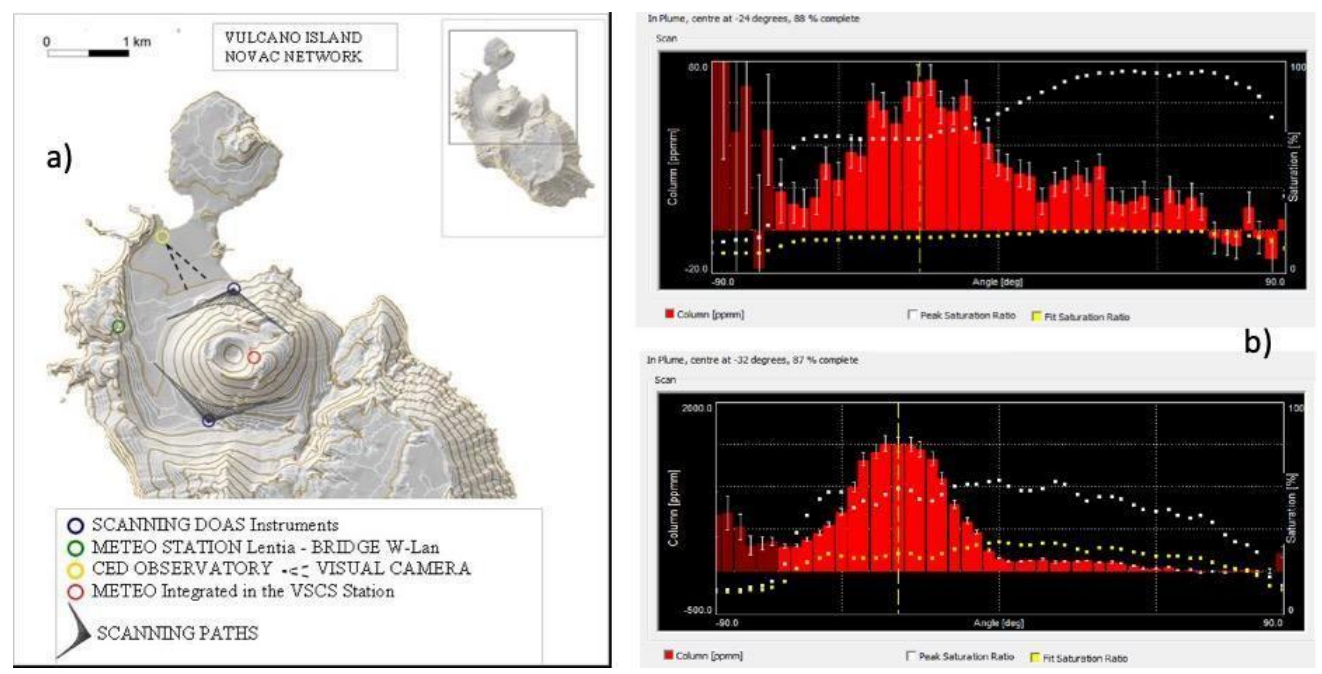

Figure 4. (a) UV scanning DOAS and conic scanning path; (b) two examples of the distribution of the plume on two measurements made under conditions of different degassing activities. The graphs were produced by the NOVAC software and show the positions of the telescope during a single measurement, from $90^{\circ}$ to $-90^{\circ}$ (X axis; horizon to horizon) for a total of 50 positions for one complete measure, and the column density of $\mathrm{SO}_{2}$ (Y axis; ppmm). The white dots represent the peak intensities of the light, and the red bars the column density for each position of the telescope during the measurement. (a) Measurement during 2020 (normal activity, ca. $14 \mathrm{t} \mathrm{d}^{-1}$ ). (b) Measurement on 12 October 2021 (increased activity, ca. $140 \mathrm{t} \mathrm{d}^{-1}$ ).

The telescope consists of a single plane-convex quartz lens with a diameter of $25.4 \mathrm{~mm}$ and a focal length of $7.5 \mathrm{~cm}$, as well as a Hoya (U330) UV filter that reduces intensity of light with wavelengths longer than $360 \mathrm{~nm}$. A stepper motor automatically moves the telescope from horizon to horizon $\left(90^{\circ}\right.$ to $\left.-90^{\circ}\right)$. At every elevation angle, 15 spectra are collected for one measurement. Every full measurement cycle contained fifty-three spectra: one Zenit sky spectrum, one dark current spectrum, one offset spectrum, and fifty measurement spectra. It usually takes about $10 \mathrm{~min}$, depending on the light conditions of the sky. The plume is scanned along a conical surface rather than a vertical one (Figure 4)this configuration significantly increases the wind direction range that can be covered by a single scanning instrument, and at the same time reduces problems related to multiple scattering effects [60]. The telescope is coupled to one (single-beam) quartz optical fiber with a diameter of $600 \mu \mathrm{m}$. This combination gives a field of view of $8 \mathrm{mrad}$. The optical fiber is coupled with the entrance slit of the spectrometer, which has a width of $50 \mu \mathrm{m}$ and height of $1 \mathrm{~mm}$. The NOVAC instruments are powered by an array of $12 \mathrm{~V}$ batteries and solar panels. A timer is added to interrupt operation of the instrument at night and reset the instrument in the morning.

The spectra are analyzed according to the DOAS procedures, based on the BeerLambert Law, to analyze the collected data and evaluate the flux [63,64]. Each spectrum is first corrected for the electronic noise (offset and dark current) and the optical density is obtained by dividing each spectrum measurement by a reference spectrum (i.e., a spectrum taken outside the plume), and then a logarithm is taken of the result of this calculation. A polynomial fit is used to take into account any broadband extinction structure caused by broadband absorption of trace gases [55,64]. A high-pass filter is applied to the absorption cross-sections to use only the remaining high-frequency structure, which is unique for any 
trace gas, and which can therefore be used to determine its abundance. Shifts and squeezes are allowed for the absorption cross-sections to compensate for any small shift, caused mainly by variations in the temperatures of the spectrometer and the detector unit [7].

\subsection{Environmental Parameters Network (Lentia and La Fossa Crater)}

The main weather station, used to elaborate the data supplied by the UV scanning DOAS, was installed on Lentia Hill (Figure 1) at an altitude comparable to that of the Fossa crater (350 $\mathrm{m}$ a.s.1.). This location ensured the same exposure to the main wind directions, and the absence of any physical barrier between the sensor positions and the fumarole field of La Fossa cone was the condition to register the best local weather variable fitting to the DOAS measurements to extrapolate the real Flux of $\mathrm{SO}_{2}$ and other associated species. The weather station "Lentia" engineered by Davis was the model Vantage Pro2 and provided the following variables: wind speed and direction, rainfall, air temperature, relative humidity, infrared radiation and UV radiation (Figure 1). The communication with the remote server was ensured by a wireless system. Acquired data passing via the Vulcano Observatory arrived at Palermo data center acquisition (INGV) in real-time, passing via the Vulcano Observatory.

A second meteorological station was integrated into the VSCS soil $\mathrm{CO}_{2}$ fluxes measurement station, located in the summit area of the La Fossa Crater. The anemometer used in this case is Wind-Sonic Gill, a 2-axis ultrasonic wind sensor, which provides data on wind speed $(0-60 \mathrm{~m} / \mathrm{s})$ and wind direction $\left(0-359^{\circ}\right)$. This ultrasonic wind sensor is ideal for use in the adverse conditions found in the crater area of Vulcano, having no moving parts to jam, break or wear out and being robust and resistant to corrosion. The SHT75 thermo-hygrometer allows the measurement of relative humidity in the air with a range of $\mathrm{Rh} \% 0-100 \%$ and air temperature with a temperature range of $\mathrm{T}-40$ to $100 \mathrm{C}^{\circ}$ (Figure 1 ).

The wind speed has been utilized inside of a NOVAC program algorithm [64-66] to calculate the flux by the concentration of the molecules in the cross-section, perpendicular to the direction of propagation of the plume (Figure 3). Local wind monitoring is crucial because any erroneous estimation of wind speed and direction of propagation results in underestimations or overestimations of the flux measurement [1]. Here, we have also tested the wind data provided by global model from European Centre for Medium-Range Weather Forecasts (ECMWF) or the National Oceanic and Atmospheric Administration (NOAA) that have been considered in other volcanic assets. We found that the global modeling of weather parameters does not fit well the local dispersion of the small volcanic plume, generated by the active cone of La Fossa, due to the actual condition affecting the dispersion of gases (e.g., low altitude of the source, small distance from the populated areas) and the position of the Vulcano Porto Village, laying very close to the main fumaroles. For these reasons, we generally used the wind data from two very local weather stations (Lentia and VSCS in Figure 1) to better evaluate the $\mathrm{SO}_{2}$ flux and better constrain the input data requested for tracking the local dispersion of noxious gases, like the sulfur dioxide of volcanic origin.

Furthermore, a UV-visible camera (MOBOTIX M25 Res. $1280 \times 720$ HD) was installed in 2016 on the roof of the Carapezza volcanological center in the direction of the volcano summit and a daily time-lapse is recorded with frames every $5 \mathrm{~min}$ (Figure 5). This camera has a dual purpose, to directly observe the degassing activity and to have direct feedback on the plume emitted from the solfataric area of the Fossa crater. This allows us to have a view of both direction and height of the plume, useful for processing the data of the slant column density of $\mathrm{SO}_{2}$ to be multiplied by the wind speed. Moreover, the visual information acquired by the UV-visible camera allows us to choose, which is the UV-scanning-DOAS station to utilize for the calculation of the output of $\mathrm{SO}_{2}$.

\subsection{Soil $\mathrm{CO}_{2}$ Fluxes, Methodology}

The most sensible site for monitoring the summit degassing and evaluating the volcanic activity level is the summit crater area, which generally releases over $90 \%$ of the total 
$\mathrm{CO}_{2}$ degassing from Vulcano Island [6]. For this reason, in September 2007, an automated soil $\mathrm{CO}_{2}$ monitoring station (VCSCS) was installed within the active summit crater of La Fossa beyond the fumarolic areas (Figure 1; the station is manufactured by West Systems ltd., [67]. Carbon dioxide was measured with a Dräger Polytron IR spectrometer, which operates in the range of 0-9999 ppm (precision of $\pm 5 \mathrm{ppm}$ ); environmental parameters (wind direction and speed, soil and atmosphere temperatures, atmospheric pressure and soil and atmosphere relative humidity) are acquired at the same time and in the same place [5]. The near-real-time measurement of $\mathrm{CO}_{2}$ fluxes (VCSCS) is carried out on an hourly basis and the data are either stored in loco or transmitted directly to the INGV-Palermo geochemical monitoring center via internet utilizing WLAN/rooter service [5]. In case of failure in the transmission system, the local storage prevents the loss of data and the time series can be updated by in situ downloading.

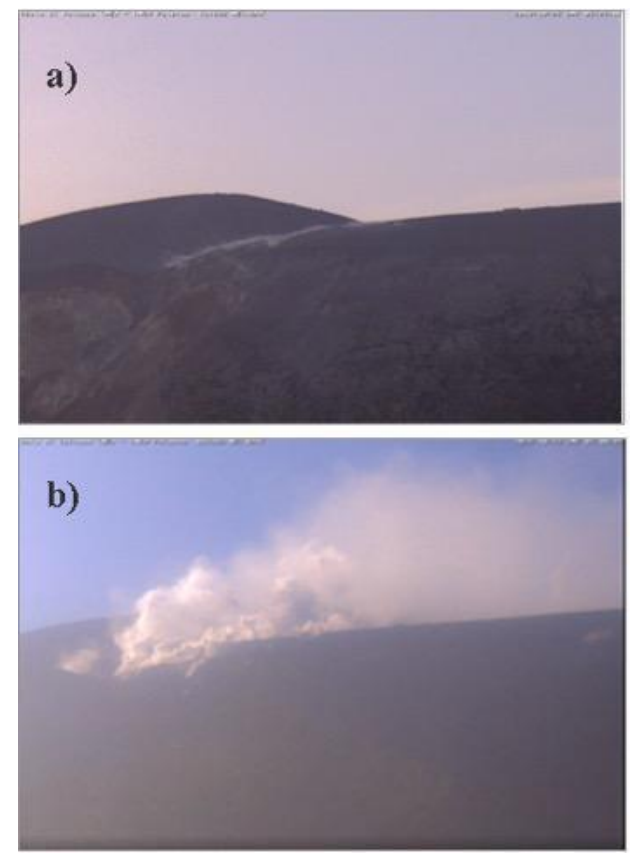

Figure 5. Photos of the Vulcano crater obtained by video monitoring. (a) View of the fluid emission from the main fumaroles field during the period of background solfataric activity degassing; (b) view of the fluid emission from the main fumaroles field during the anomalous degassing of 2021 crisis.

\subsection{Soil $\mathrm{CO}_{2}$ Output, Methodology and Campaigns}

The last survey of diffuse soil $\mathrm{CO}_{2}$ flux, in order of time, was carried out on 30 September 2021, in coincidence with the maximum $\mathrm{CO}_{2}$ emission $\left(34,000 \mathrm{~g} \mathrm{~m}^{2} \mathrm{~d}^{-1}\right)$ from soils, recorded by the VCSCS station. The survey was performed with the West Systems equipment on 164 points located in the summit area of the active cone of La Fossa, exactly in the same target area of the 2007 survey [6] outside of the main fumarole field. These $\mathrm{CO}_{2}$ flux data have been plotted on a normal probability plot [68] to assess the anomaly threshold for soil $\mathrm{CO}_{2}$ flux and differentiate among different populations of soil $\mathrm{CO}_{2}$ flux, following a Graphical Statistical Approach (GSA). Soil $\mathrm{CO}_{2}$ flux data were processed for surface mapping using the sequential Gaussian simulation $[69,70]$ (sGs), and this stochastic simulation allowed the best interpolation of the sets of data and evaluation of the output of diffuse $\mathrm{CO}_{2}$ flux associated with the standard deviation of the total $\mathrm{CO}_{2}$ output. The soil diffuse $\mathrm{CO}_{2}$ output has been extended to cover the crater, except the fumarole area, and has been compared to the results of the 2007 survey [6].

\subsection{Thermal Gradient and Heat Fluxes}

The dataset of ground temperatures consists of temperature measurements in the porous ground (loose volcanic breccia) recorded on the west of the high-temperature 
fumarole vents located on the northern slope of the active cone of La Fossa caldera. The temperature data were recorded at the VSCS station (Figure 1) on a vertical line of four PT1000 sensors (temperature range of $-40{ }^{\circ} \mathrm{C}$ to $150{ }^{\circ} \mathrm{C}$, accuracy $\pm 0.2{ }^{\circ} \mathrm{C}$, resolution $\pm 0.1^{\circ} \mathrm{C}$ ), the distance between each sensor was $0.15 \mathrm{~m}$, and thus the total depth of the monitored profile was $0.60 \mathrm{~m}$. The temperature data were recorded hourly.

The measured profile is located a short distance $(2 \mathrm{~m})$ from the accumulation chamber for the diffuse $\mathrm{CO}_{2}$ flux monitoring in order to monitor both the heat and gas flux at the same time and in the same diffuse degassing zone (Figure 2D). Therefore, temperature data in the shallowest layer of ground have been stored in the same server at the same time as $\mathrm{CO}_{2}$ flux data diffusely released there.

The diffuse gas emission is essentially $\mathrm{CO}_{2}$ because the main component of the hydrothermal advection, which is water vapor, has in this case condensed just below the conductive layer, and all the other condensable species are trapped in the liquid phase within the saturated ground. Therefore, temperature data in the shallowest layer of ground have been stored in the same server at the same time as $\mathrm{CO}_{2}$ flux data diffusely released there.

These areas of mild thermal anomaly were named sub-fumarole area by [70,71] or steam heated soil (SHS) by other authors [1]. The method for measuring the heat flux from a shallow profile of temperature in volcanic areas was developed by [70] and further applied in continuous monitoring mode by other authors such as [72,73]. At the best condition, the monitored profile is almost dry (low humidity and absence of a liquid phase and steam) and the condensation zone of the steam ascending from the deep magmatic source stands at a short distance from the bottom of the profile along the z-axis [73]. In this almost-dry condition, the continuous monitoring of the diffuse heat flux associated with the thermal grounds has been ensured for long-term acquisition and avoided frequent interpolations due to missing data, or not-ideal conditions of the site.

The main issue in managing temperature data from the SHS monitoring stations is that the result is strongly site-sensitive, so the thermal monitoring profile must be located in steam-heated soils, along active faults, eruptive fractures or close to active fumaroles conduits, to promptly highlight magmatic impulses or new changes of trends. The heat flux monitored on the earth's surface is indeed the result of the combined effect of forces of opposite origin - the endogenous geothermal source, generated by buried magma on one side and the exogenous radiative source of sun on the other side. Another issue is the high sensitivity of the shallow ground to the natural changes of external conditions because rainfall, strong winds and sun radiations strongly perturb the ground temperature of the shallow layer of ground. The synchronous monitoring of atmospheric variables at the local scale and the cross-correlation with other volcanic variables, independently monitored, are strongly recommended in order to avoid erroneous interpretation of the temperature trends. In general, the best location for the temperature monitoring profile is at same distance from a fumarole vent, where the steam advection degrades from the convective to the diffusive transfer, and therefore the temperature distribution within the ground (thermal gradient and depth of the massive convective front) becomes the main variable to be directly correlated to the local heat flux. The previous monitoring experiences $[33,73]$ proved that the best location for the temperature monitoring profile is at same distance from fumarole vents, where the steam advection degrading from the convective to the diffusive transfer is the best location for the temperature monitoring profile. In this case, the temperature distribution within the ground (thermal gradient and depth of the massive convective front) becomes the main variable directly correlating with the local heat flux. In the SHS, the main changes of thermal gradient result in changes to the conductive heat flow, but also in changes in the depth of the massive convective front, reflecting any contraction or expansion of the convective zone manifested by the neighboring fumaroles.

\subsubsection{Depth Limit of the Conductive Layer (Z1)}

The depth limit of the conductive layer (Z1) was calculated based on the temperature gradient following the hypothesis that the monitored profile was dry and the conductive 
heat transfer law dominated. The profiles showing a linear fit coefficient $(R$, calculated on 4 contemporary temperatures) lower than 0.99 indicated not ideal condition. The local temperature variation/depth range $(\mathrm{Dt} / \mathrm{Dz})$ slope, measured along the shallow ground profile to a maximum depth of $0.6 \mathrm{~m}$, indicated the temperature distribution in the uppermost ground layer when the heat transport was essentially conductive. Extrapolation of each linear slope to the local boiling point $\left(100^{\circ} \mathrm{C} ; 1 \mathrm{~atm}\right)$ indicated the $\mathrm{Z} 1$ at the VSCS station at the recording time. Thus, by extrapolating the linear profiles of temperature to the boiling point, we can evaluate the local changes in Z1 and also track the vertical shifts of the massive convective front throughout the monitoring period by following the time variations of Z1. Figure 6 gives an example of the linear thermal gradient (red line and equation) used to evaluate the depth limit of the conductive layer (Z1), that is the shallowest depth of the convective front, with the logarithm equation also fitting the air temperature and the resulting boiling point (blue curve and equation). $\mathrm{R}^{2}$ is the correlation value for the correspondent regression. The temperature values in the example of Figure 6 $X$ were recorded in January 2019, the $1^{\circ}$ at $\mathrm{H} 12: 00$. When the heat release increases the convective front moves toward the interface between air, the local condition and the site could turn from sub-fumarole to fumarole condition. In this case, the linear regression coefficient results get lower than 0.990 and the thermal gradient is low because the diffuse heat flux becomes just a minor component of the heat release; more undetected variables should be investigated to quantify the real heat flux leaving the ground.

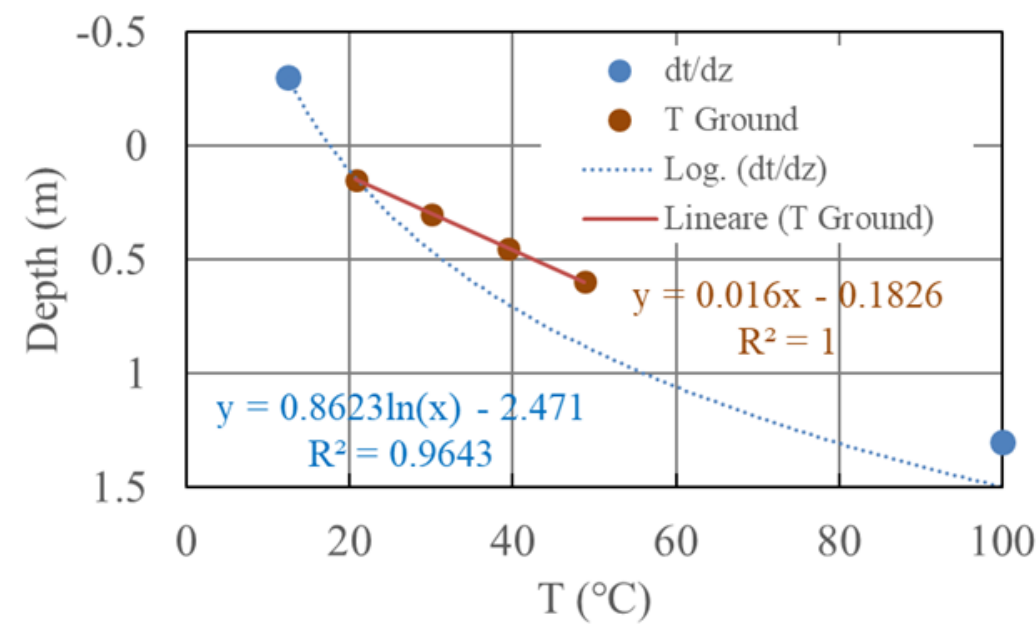

Figure 6. Example of a ground profile showing the thermal gradient in dry ground condition (brown circles) and air temperature (blue circle) recorded at the VSCS station. The brown line and equation show the linear gradient extrapolated to the depth limit of the conductive layer (Z1); the blue curve and equation shows the logarithm equation also fitting the air temperature. $\mathrm{R}^{2}$ is the correlation value for the correspondent regression.

\subsubsection{Heat Flux of the Steam Heated Ground (SHS-Flux)}

The heat flux of the steam heated ground (SHS-Flux) is calculated in the superficial ground zone (above the Z1 level), using the following heat flux equation simplified by [74]:

$$
\text { SHS-Flux }=\lambda(\mathrm{t} 4-\mathrm{t} 2) /(\mathrm{zt} 4-\mathrm{zt} 2)
$$

where $t 4$ and $t 2$ are the temperatures, measured along the shallow vertical profiles at different depths $(\mathrm{zt} 4=-0.6 \mathrm{~m} ; \mathrm{zt} 2=-0.3 \mathrm{~m})$ and $\lambda$ is the thermal conductivity, which, in the dry ground conditions requested for SHS flux evaluations, is assumed to be constant for a specific site (in this case we applied the value $\lambda=0.8 \mathrm{~W} \cdot \mathrm{m}^{-1} \cdot \mathrm{K}^{-1}$, in accordance with [37-74]). In order to minimize the sun radiation effect, the SHS-Flux was calculated based on the temperature gradient, excluding the uppermost sensor of temperature (T1 at depth of $0.15 \mathrm{~m}$ ). When/if the temperature of the sensors in the ground increases to 
more than $70{ }^{\circ} \mathrm{C}$, the temperature gradient is no more linear and the convective component of the heat flux becomes dominant. In this case, steam is the main component in the porous ground, and the monitored layer loses the ideal dry condition requested for the total conductive heat transfer. When the ground temperature of the monitored profile is higher than $70^{\circ} \mathrm{C}$, the SHS monitoring system can still supply the real start and end time of the increased heat release, but in this instance, the evaluated heat flux is highly underestimated, not including the convective heat transfer, that is-temporary-the main component of the local heat flux.

\section{Results}

\section{1. $\mathrm{SO}_{2}$ Plume Fluxes}

The $\mathrm{SO}_{2}$ plume fluxes monitored from 2008 to 2021 showed values between 7 and $248 \mathrm{t} \mathrm{d}^{-1}$ (Figure 7), with an average value of $25 \mathrm{t} \mathrm{d}^{-1}$. In the following discussion, this last value, plus the standard deviation, will be considered the actual threshold value $\left(25+/-21 \mathrm{t} \mathrm{d}^{-1}\right)$ to indicate the background convective outgassing, sourced from the high-temperature fumarole field of the La Fossa cone.

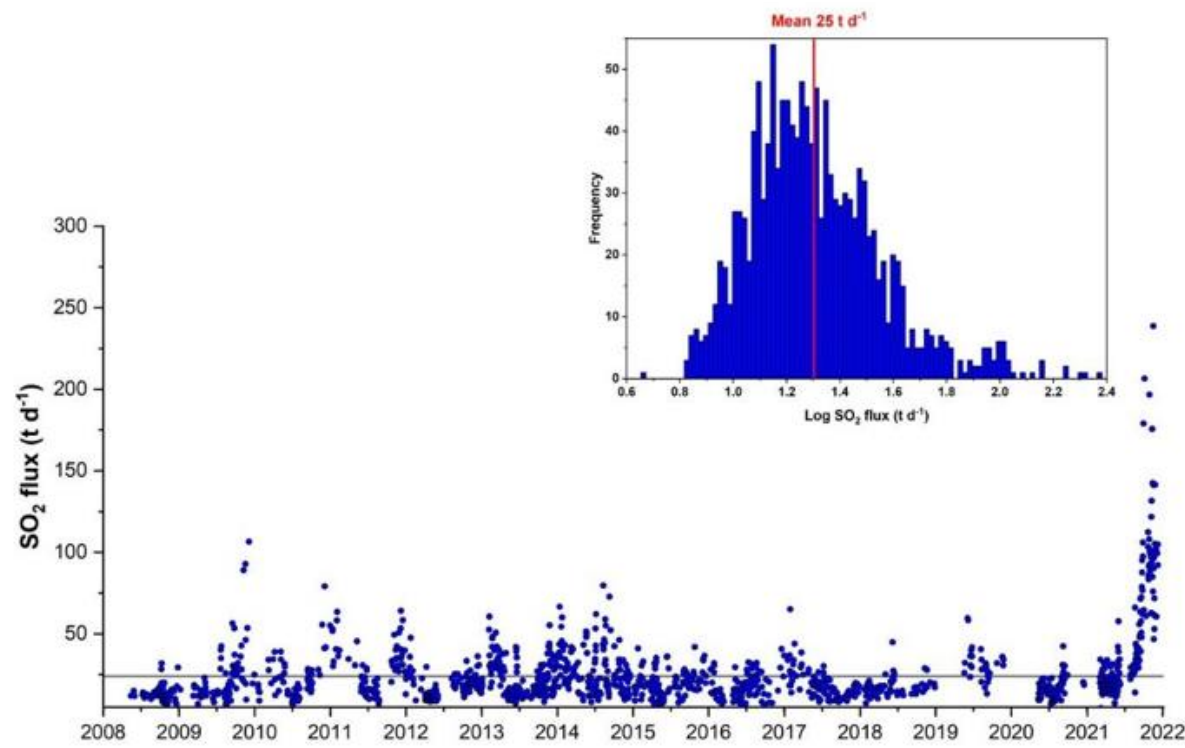

Figure 7. Daily average of $\mathrm{SO}_{2}$ fluxes from the volcanic plume of the 2008-2021 period. Histogram of the $\mathrm{SO}_{2}$ fluxes data with a mean value of $25 \mathrm{t} \mathrm{d}^{-1}$.

Two major peaks in outgassing were observed in detail in September-December 2009, respectively (Inguaggiato et al. 2012), which reached values of $\mathrm{SO}_{2}$ fluxes of around $100 \mathrm{t} \mathrm{d}^{-1}$; and the ongoing stronger increases occurred in September-December 2021 with flux values that had abundantly exceeded $200 \mathrm{t} \mathrm{d}^{-1}$, up to a maximum value of $248 \mathrm{t} \mathrm{d}^{-1}$ to date (one order of magnitude over the mean value of the last 13 years). To date, the last period of anomalous outgassing is still ongoing (31 December 2021).

In addition, several smaller increases with peaks of 75, 60, 50 and $40 \mathrm{t} \mathrm{d}^{-1}$ respectively occurred over the long observation period. During 2015, on the other hand, lower degassing values were recorded for the whole year, and the $\mathrm{SO}_{2}$ flux values slightly exceeded the average value of $25 \mathrm{t} \mathrm{d}^{-1}$.

\subsection{Soil $\mathrm{CO}_{2}$ Fluxes}

The fluxes of $\mathrm{CO}_{2}$ from the soils measured at the VSCS station represented the time variations of diffuse gas emissions from the summit of the active cone of the island of Vulcano in the period 2007-2021. The monitoring station showed values between 100 and $34,000 \mathrm{~g} \mathrm{~m}^{-2} \mathrm{~d}^{-1}$, with an average value of $1637 \mathrm{~g} \mathrm{~m}^{-2} \mathrm{~d}^{-1}$ (Figure 8). The two largest increases in the diffuse $\mathrm{CO}_{2}$ fluxes from the ground occurred respectively in the period September-December 2009 [5], with values of 14,000 $\mathrm{g} \mathrm{m}^{-2} \mathrm{~d}^{-1}$, and from September to 
December 2021, with the highest values of 34,000 $\mathrm{g} \mathrm{m}^{-2} \mathrm{~d}^{-1}$. After the peak occurred in 2009, a general decreasing trend, with minor peaks, was observed until the 2015 period, when the lowest fluxes (around $100 \mathrm{~g} \mathrm{~m}^{-2} \mathrm{~d}^{-1}$ ) were observed. Thereafter, starting from 2016 onwards, a reversal in the diffuse degassing trend has been observed, with a series of increasing peaks in 2016, 2017, 2018 and 2019. However, in these previous years, the maximum values of soil $\mathrm{CO}_{2}$ fluxes never exceeded $5000 \mathrm{~g} \mathrm{~m}^{-2} \mathrm{~d}^{-1}$. Starting from 2020 onwards, the VSCS station showed a main positive trend of diffuse gas emissions with flux values increasing from $500 \mathrm{~g} \mathrm{~m}^{-2} \mathrm{~d}^{-1}$ to $34,000 \mathrm{~g} \mathrm{~m}^{-2} \mathrm{~d}^{-1}$, recorded on 30 September 2021. This value, reached in September, represented an increase of 20 times higher with respect to the average values evaluated in 13 years of observation.

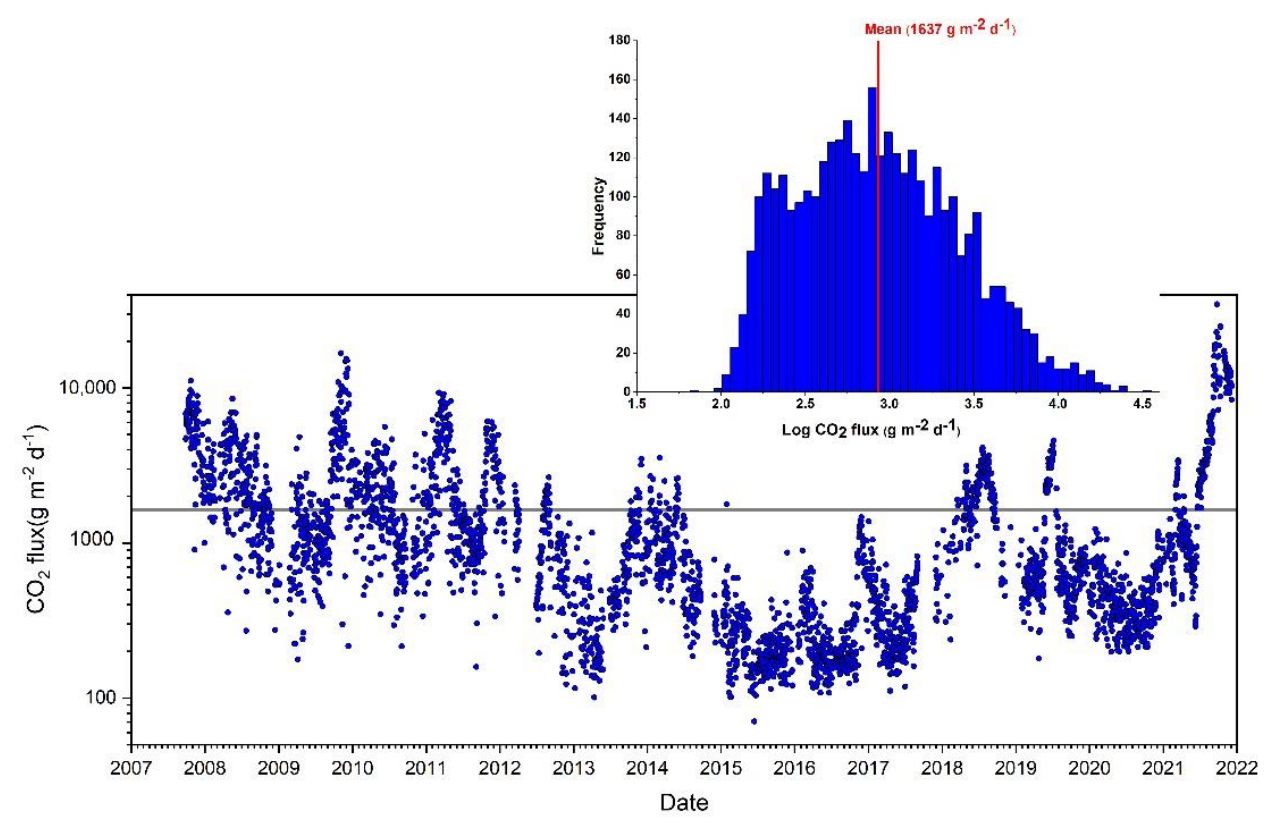

Figure 8. Daily average (24 measurements/day) of $\mathrm{CO}_{2}$ fluxes of VSCS station of the 2007-2021 period. Histogram of the $\mathrm{CO}_{2}$ fluxes data with a mean value of $1637 \mathrm{~g} \mathrm{~m}^{-2} \mathrm{~d}^{-1}$.

\subsection{Soil $\mathrm{CO}_{2}$ Output}

On 30 September 2021, the survey of $\mathrm{CO}_{2}$ fluxes in a target area of La Fossa caldera has been carried out to detect the ongoing strong increases of soil $\mathrm{CO}_{2}$ fluxes recorded in the summit area by the VCSCS station. This survey started in coincidence with the maximum $\mathrm{CO}_{2}$ fluxes recorded in the summit area by the VCSCS station, $\left(34,000 \mathrm{~g} \mathrm{~m}^{-2} \mathrm{~d}^{-1}\right)$. The total output of $\mathrm{CO}_{2}$ degassing from the soils in this area has been estimated as $1548 \mathrm{t} \mathrm{d}^{-1}$ (see Table 1 for sGs statistics and reference surfaces). This $\mathrm{CO}_{2}$ flux value was around 16 times higher than the 2007 campaigns (92 $\mathrm{t} \mathrm{d}^{-1}$; Figure 4; [6]), although they were performed on the same target area of comparable extension (Table 1). In both the surveys, the targeted area excluded the sector interested by the main fumarole release (Figure 9); moreover, the last survey confirmed $\mathrm{CO}_{2}$ fluxes by the VCSCS station as representative of the whole summit degassing of the crater area of this active cone.

Table 1. Summit area $\mathrm{CO}_{2}$ flux output $\left(\mathrm{t} \mathrm{d}^{-1}\right)$.

\begin{tabular}{|c|c|c|c|c|c|}
\hline Date & $\begin{array}{l}\text { Number of } \\
\text { Samples }\end{array}$ & $\begin{array}{l}\text { Area } \\
\left(\mathrm{m}^{2}\right)\end{array}$ & $\begin{array}{c}\text { Total } \mathrm{CO}_{2} \\
\text { Output } \\
\text { (t/d) }\end{array}$ & $\begin{array}{c}\text { Standard } \\
\text { Deviation } \\
\text { (t/d) }\end{array}$ & $\begin{array}{c}\text { Total } \mathrm{CO}_{2} \text { Output (t/d) } \\
\text { Area of } 440,755 \mathrm{~m}^{2}\end{array}$ \\
\hline Sep-2021 & 164 & 88,900 & 312 & 7.1 & 1547 \\
\hline Sep-2007 & 244 & 70,575 & 15 & 0.6 & 94 \\
\hline
\end{tabular}


2007
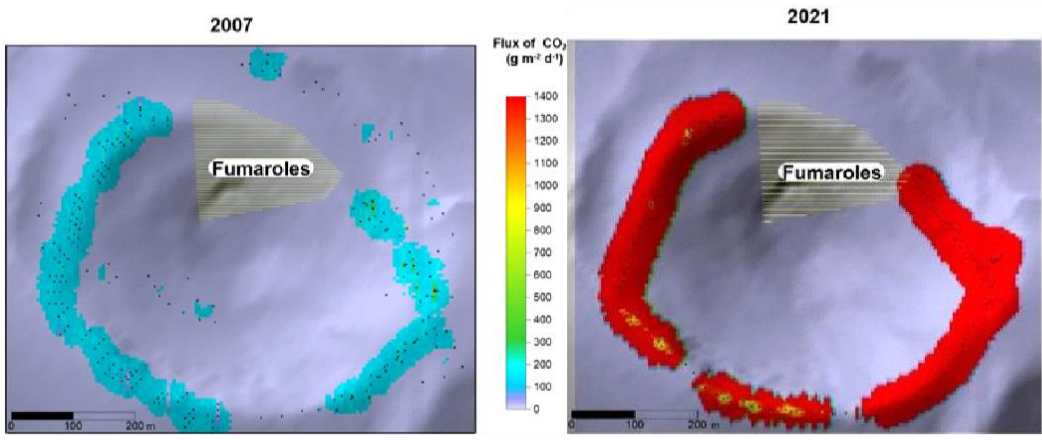

Figure 9. Summit soil degassing area maps relative to 2007 and 2021; the brown field shows the main fumarole release. The distribution of $\mathrm{CO}_{2}$ flux over the summit area and estimates of the total $\mathrm{CO}_{2}$ discharge were derived by sequential Gaussian simulation (sGs).

The probability plot resulting from the flux measured in the last survey (Figure 10a and Tables 1 and 2) shows a three-modal distribution, consisting of three lognormal populations named A, B and C, with a partial overlapping of the samples in (A) and (B). Based on the GSA technique proposed by [69], the mean $\mathrm{CO}_{2}$ flux and the $95 \%$ confidence interval of the mean [74] are for the population (A) $606 \mathrm{~g} \mathrm{~m}^{-2} \mathrm{~d}^{-1}\left(336-1679 \mathrm{~g} \mathrm{~m}^{-2} \mathrm{~d}^{-1}\right)$; for the population (B) $1343 \mathrm{~g} \mathrm{~m}^{-2} \mathrm{~d}^{-1}\left(1150-1629 \mathrm{~g} \mathrm{~m}^{-2} \mathrm{~d}^{-1}\right)$; and for the population (C) $13,518 \mathrm{~g} \mathrm{~m}^{-2} \mathrm{~d}^{-1}\left(12,816-14,789 \mathrm{~g} \mathrm{~m}^{-2} \mathrm{~d}^{-1}\right)$.
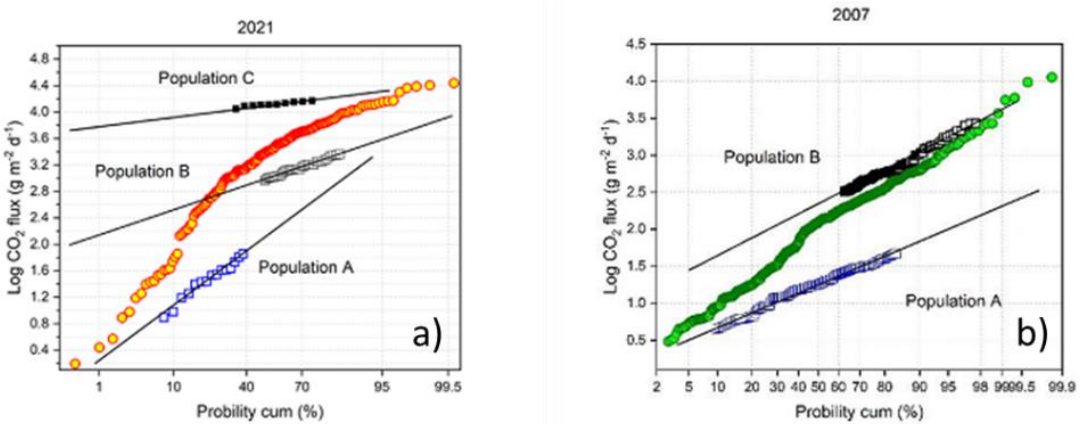

Figure 10. (a) $\log \mathrm{CO}_{2}$ fluxes vs the cumulated probability (\%) of the 2007 survey; (b) $\log \mathrm{CO}_{2}$ fluxes vs the cumulated probability (\%) of the 2021 survey. Both surveys were performed at the summit area.

Table 2. Proportions of each population with a mean $\mathrm{CO}_{2}$ flux $\left(\mathrm{in} \mathrm{g} \mathrm{m}^{-2} \mathrm{~d}^{-1}\right.$ ) and the corresponding $90 \%$ confidence intervals obtained by statistical graphical approach.

\begin{tabular}{|c|c|c|c|}
\hline \multicolumn{4}{|c|}{ Crater 2021} \\
\hline $\begin{array}{l}\text { Population } \\
\text { of } \mathrm{CO}_{2} \text { Flux }\end{array}$ & $\begin{array}{l}\text { Mean Flux of } \\
\mathrm{CO}_{2} \\
\left(\mathrm{~g} \mathrm{~m}^{-2} \mathrm{~d}^{-1}\right)\end{array}$ & $\begin{array}{c}90 \% \\
\text { Confidence } \\
\text { Interval } \\
\left(\mathrm{g} \mathrm{m}^{-2} \mathrm{~d}^{-1}\right)\end{array}$ & $\begin{array}{c}\text { Proportion } \\
\text { (\%) }\end{array}$ \\
\hline A & 606 & $336-1679$ & 29 \\
\hline B & 1343 & 1150-1629 & 57 \\
\hline $\mathrm{C}$ & 13,518 & $12,816-14,789$ & 14 \\
\hline \multicolumn{4}{|c|}{ Crater 2007} \\
\hline $\mathrm{A}$ & 30 & $28-34$ & 40 \\
\hline B & 455 & $414-512$ & 60 \\
\hline
\end{tabular}

The results of the GSA for the data measured in September 2021 highlights two new populations characterized by high $\mathrm{CO}_{2}$ flux that were never registered before (Figure $10 \mathrm{~b}$ and Tables 1 and 2) [5], suggesting a new and more active degassing level, possibly of magmatic origin. 


\subsection{Thermal Monitoring}

The thermal monitoring of diffuse heat flux from the marginal zone of the hightemperature fumarole field of the active cone of La Fossa Caldera began in April 2018. For more than three years, we registered the hourly variation of temperature in the section of the ground crossed by diffuse gas emission. Both the depth limit of the conductive layer (z1 depth) and the diffuse heat flux resulted in the hourly monitored shallow temperature gradient. The period from June 2018 to June 2019 was characterized in general by background solfataric activity, as can be confirmed by comparing the general report of volcanic surveillance. For this reason, the average value of the $\mathrm{z} 1$ depth, extrapolated during the same period, represents the reference value of the depth limit of steam condensation during the background degassing. The time variations of Z1 depth (Figure 9) show that the z1 depth has been generally deeper than $-0.9 \mathrm{~m}$, except in July 2018, during summer 2019 (from the end of May to 8 August) and from 26 June to the end of 2021 (Figure 11). From 28 September to 11 October, the Z1 depth rose (see Figure 10) and the monitored profile included a narrow level interested by mixed heat transfer (above a depth of $0.4 \mathrm{~m}$, both conductive and convective) while the deepest part was essentially convective (below a depth of $0.4 \mathrm{~m}$ ), and two levels reached the same maximum temperature of $93{ }^{\circ} \mathrm{C}$. The shallowest depth limit of the conductive layer was registered on 11 October 2021 and rose to $-0.4 \mathrm{~m}$ below the ground level.

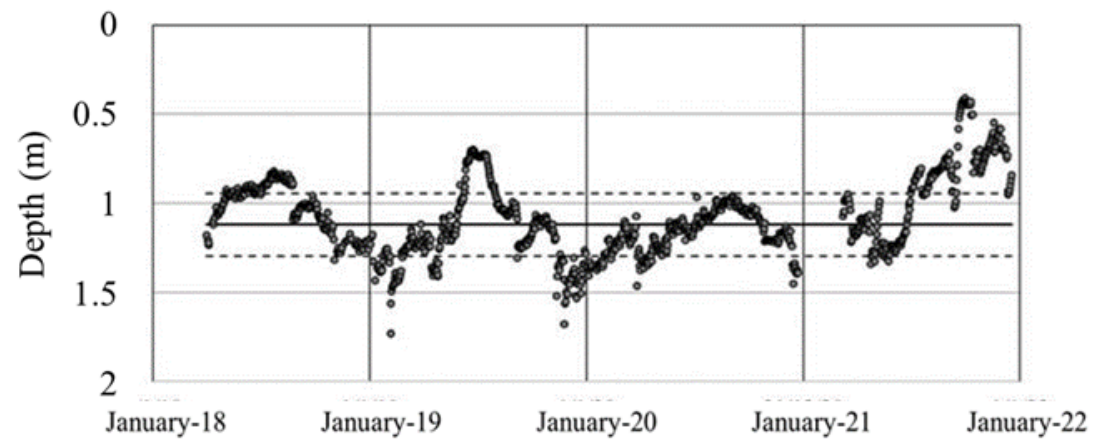

Figure 11. Time variation of the depth limit of the conductive layer recorded at VSCS station. The dashed lines indicate the standard deviation around the average value, evaluated during the period of background diffuse degassing (June 2018-June 2019).

This long-term monitoring of the thermal anomaly in this diffuse degassing zone also suggested the statistic threshold value for normal SHS flux values representing the background activity (Figure 12). The heat flux included in the range of values from 43 to $50 \mathrm{w} \times \mathrm{m}^{-2}$ (average value plus standard deviation evaluated during the first year, June 2018-2019) indicates the normal background oscillation of heat flux emitted from the ground by the diffusive layer, while all the heat flux values higher than the average, plus the standard deviation, indicate periods of anomalous heat release. The most intense impulses of diffuse heat flux have been recorded in the year 2021, with the longest and most intense heat flux release starting after 28 August. From 20 September to 14 October, the station showed values higher than $65 \mathrm{w} \times \mathrm{m}^{2}$, but these values highly underestimated the local heat output, because the convective heat transfer (undetermined by the SHS monitoring station) has been the dominant form of heat transfer along the profile after 17 September 2021. Indeed, from 28 September to 10 October 2021, we observed the highest temperature values ever recorded at this site, and two levels of the recorded profile reached the buffered temperature of $93^{\circ} \mathrm{C}$. This thermal record is our reference to indicate the acme of the actual exhalative crisis by measuring the effect directly (i.e., by contact sensors) on the thermal anomaly located in the summit area at La Fossa caldera. According to the VSCS monitoring station, the thermal effect of the volcanic unrest has been evident from the end of June 2021 and has remained persistent to the end of the year 2021, as indicated by the rate of increase of the ground temperatures, registered again after any external perturbation occurred in 
the last three months. However, starting on the night of 29 September 2021, very strong winds and intense rainfall events highly perturbed the soil gas emission, often causing sudden decreases in the shallow ground temperatures.

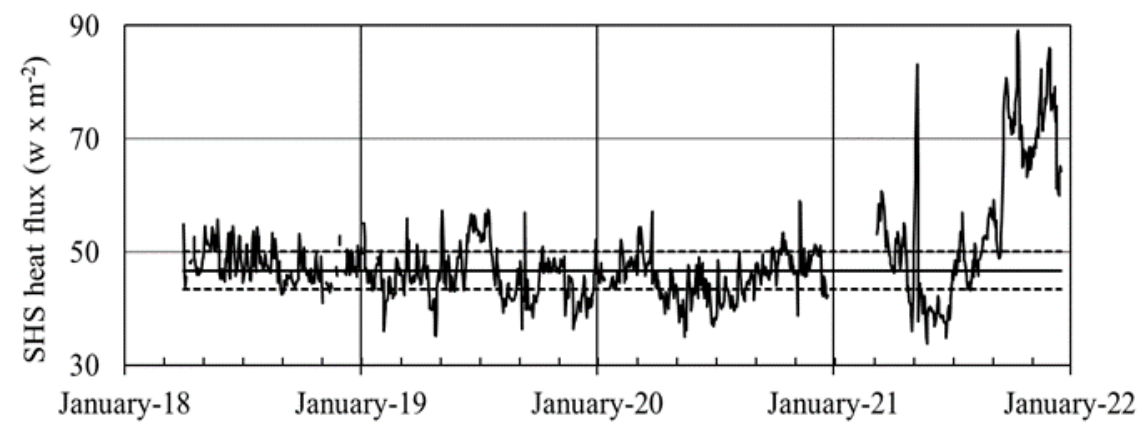

Figure 12. Time variation of diffuse heat flux recorded in the sub-fumarole area since April 2018. The grey area includes the average value and standard deviation evaluated during the period of background diffuse degassing (June 2018-June 2019).

\section{Discussion}

The plumbing system of this volcanic island is fed by deep magmatic input and is modulated by the overlying hydrothermal system $[5,9,22]$ which is able to absorb or release its volatile compounds as a function of the dynamic input/output energy balance. The volatiles fluxes monitored on the summit area of the La Fossa cone during the solfataric activity represent the main surface manifestation of the shallow plumbing system.

In particular, the time variations of both $\mathrm{SO}_{2}$ and $\mathrm{CO}_{2}$ fluxes, tracked by the respective monitoring stations since 2008, have shown two major increases of solfataric activity, highlighted by evident anomalies both in the convective and in the conductive transfer of gases occurring in 2009 and 2021. Furthermore, in the long-term, the diffuse gas emissions showed that a decreasing trend characterized the period from 2009 to 2015, while an opposite, increasing trend has been registered from 2016 to 2021. Taking into account the diffuse degassing, we can divide the entire observation period (2007-2021) into two sub-periods, 2008-2014 (Figure 13) and 2016-2021 (Figure 14) for both recorded parameters $\left(\mathrm{SO}_{2}\right.$ and $\mathrm{CO}_{2}$, to better understand the degassing processes in progress.

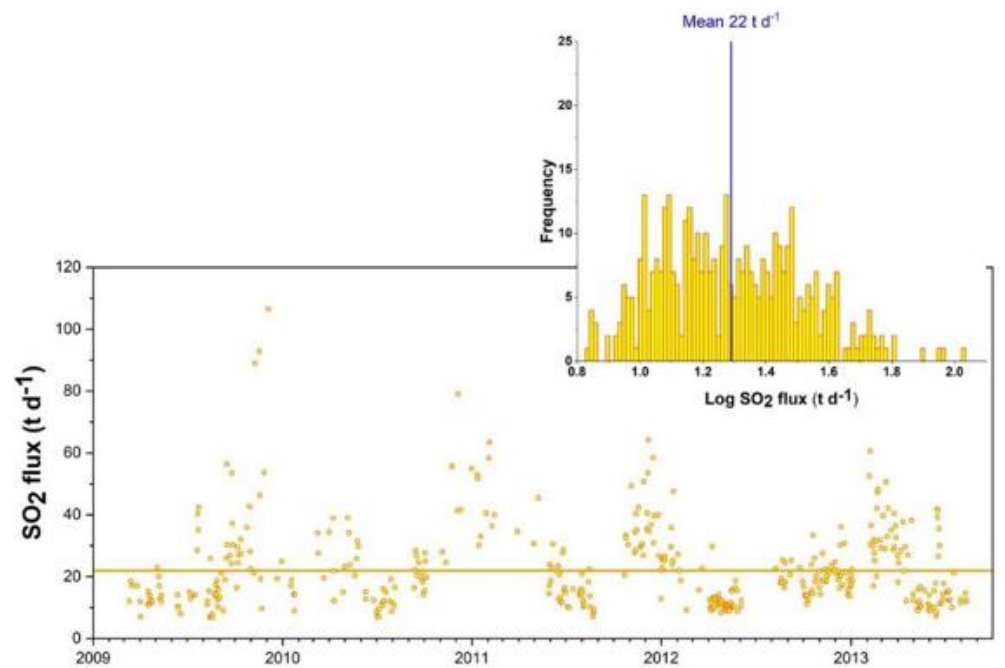

Figure 13. Daily average of $\mathrm{SO}_{2}$ fluxes from the volcanic plume of the 2008-2014 period. Histogram of the $\mathrm{SO}_{2}$ fluxes data with a mean value of $22 \mathrm{t} \mathrm{d}^{-1}$.

Moreover, after the anomalous degassing in $2009, \mathrm{SO}_{2}$ flux underwent a progressive decrease from $104 \mathrm{t} \mathrm{d}^{-1}$ down to $40 \mathrm{t} \mathrm{d}^{-1}$ in 2014, showing for this sub-period the average value of $24 \mathrm{t} \mathrm{d}^{-1}$ (Figure 13). 


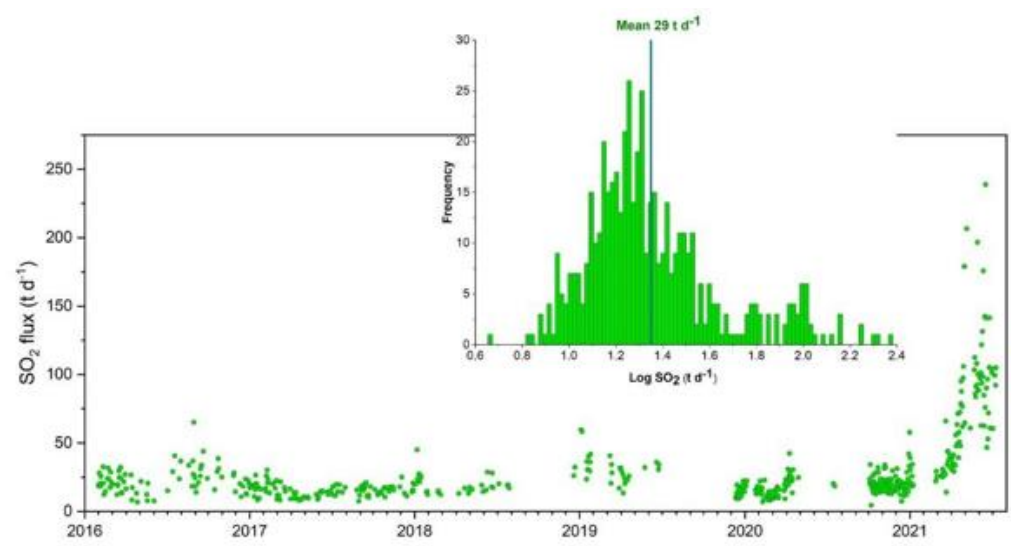

Figure 14. Daily average of $\mathrm{SO}_{2}$ fluxes from the volcanic plume of the 2016-2021 period. Histogram of the $\mathrm{SO}_{2}$ fluxes data with a mean value of $29 \mathrm{t} \mathrm{d}^{-1}$.

The second sub-period, from 2016 to 2021, has been characterized by the average value of $29 \mathrm{t} \mathrm{d}^{-1}$, a generally more sustained outgassing, and several small anomalies in 2016, 2018 and 2019, showing values exceeding $50 \mathrm{t} \mathrm{d}^{-1}$. Finally, the strongest increase in the convective degassing has begun in April 2021 and reached values up to $250 \mathrm{t} \mathrm{d}^{-1}$, an order of magnitude higher than the average value in September-October 2021 (Figure 14).

The behavior of the two sub-periods is better visualized by GSA, as shown in Figure 15 and in Table 3. In detail, the 2008-2014 period was characterized by a unimodal distribution of degassing families, while the 2016-2021 period has been characterized by the bimodal distribution with two different degassing families with frequencies of $86 \%$ and $14 \%$, respectively.
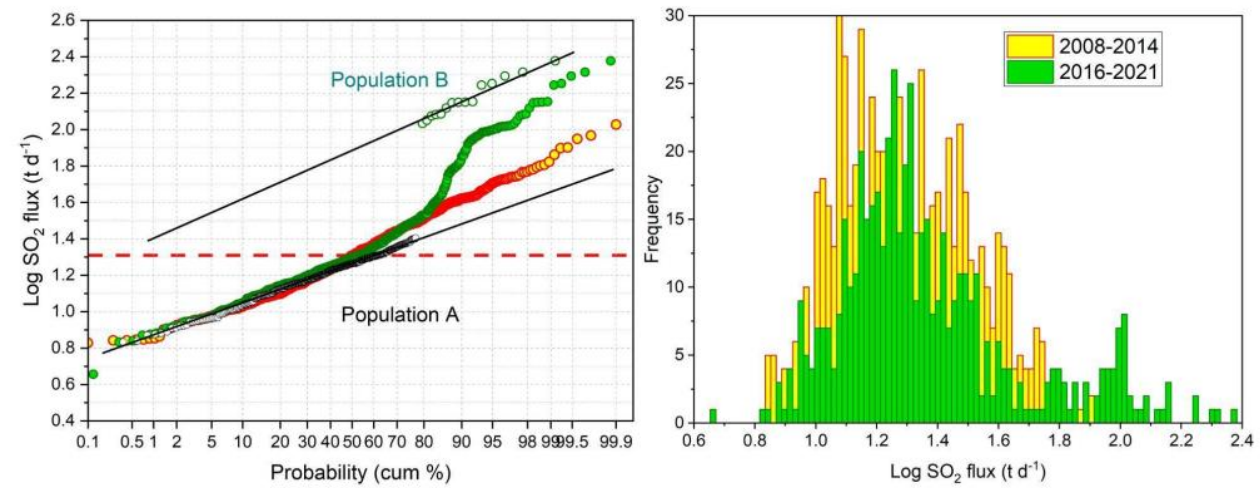

Figure 15. Partition of the $\mathrm{SO}_{2}$ flux measurements recorded daily from the active DOAS monitoring system, according to the method of Graphical Statistical Approach proposed by [50].

Table 3. Results of the partition shown in Figure 14 of the $\mathrm{SO}_{2}$ flux measurements recorded daily from the active DOAS monitoring system, based on the method of Graphical Statistical Approach proposed by [68].

\begin{tabular}{cccc}
\hline $\begin{array}{c}\text { Population } \\
\text { of } \mathrm{SO}_{2} \text { Flux }\end{array}$ & $\begin{array}{c}\text { Mean Flux of } \\
\mathbf{S O}_{\mathbf{2}} \\
\left(\mathbf{t} \mathbf{~ d}^{-\mathbf{1}}\right)\end{array}$ & $\begin{array}{c}\mathbf{9 0 \%} \\
\text { Confidence } \\
\text { Interval } \\
\mathbf{( t ~ d ~ d ) ~}^{-\mathbf{1}}\end{array}$ & $\begin{array}{c}\text { Proportion } \\
\mathbf{( \% )}\end{array}$ \\
\hline $\mathrm{A}$ & 19.5 & $18.8-20.4$ & 86 \\
\hline $\mathrm{B}$ & 85 & $77-95$ & 14 \\
\hline
\end{tabular}

The monitoring station for the diffuse degassing of $\mathrm{CO}_{2}$ highlighted a clearer discontinuity between the two sub-periods, also highlighted by GSA on the $\mathrm{SO}_{2}$ flux data. The first sub-period from 2008 to 2014 (Figure 16) is characterized by a major anomaly in 2009 
$\left(11,000 \mathrm{~g} \mathrm{~m}^{-2} \mathrm{~d}^{-1}\right)$, but also by an average value of approximately $1720 \mathrm{~g} \mathrm{~m}^{-2} \mathrm{~d}^{-1}$ and by a series of decreasing peaks of $\mathrm{CO}_{2}$ flux values reaching 6000,4000 and $2500 \mathrm{~g} \mathrm{~m}^{-2} \mathrm{~d}^{-1}$, respectively, in the period 2010-2012. Finally, in 2013-2015, the $\mathrm{CO}_{2}$ flux diffused from the ground at the summit station VSCS reached the absolute minimum value of about $100 \mathrm{~g} \mathrm{~m}^{-2} \mathrm{~d}^{-1}$, while the second sub-period from 2016 to 2021 (Figure 17) showed a series of increasing $\mathrm{CO}_{2}$ flux peaks at 2000, 4000 and $5000 \mathrm{~g} \mathrm{~m}^{-2} \mathrm{~d}^{-1}$, respectively, in 2016, 2018 and 2019, corresponding to subsequent $\mathrm{CO}_{2}$ pulses. Finally, the second half of 2020 was characterized by a growing trend, which increased almost continuously until SeptemberOctober 2021, reaching the highest recorded values of $34,000 \mathrm{~g} \mathrm{~m}^{-2} \mathrm{~d}^{-1}$.

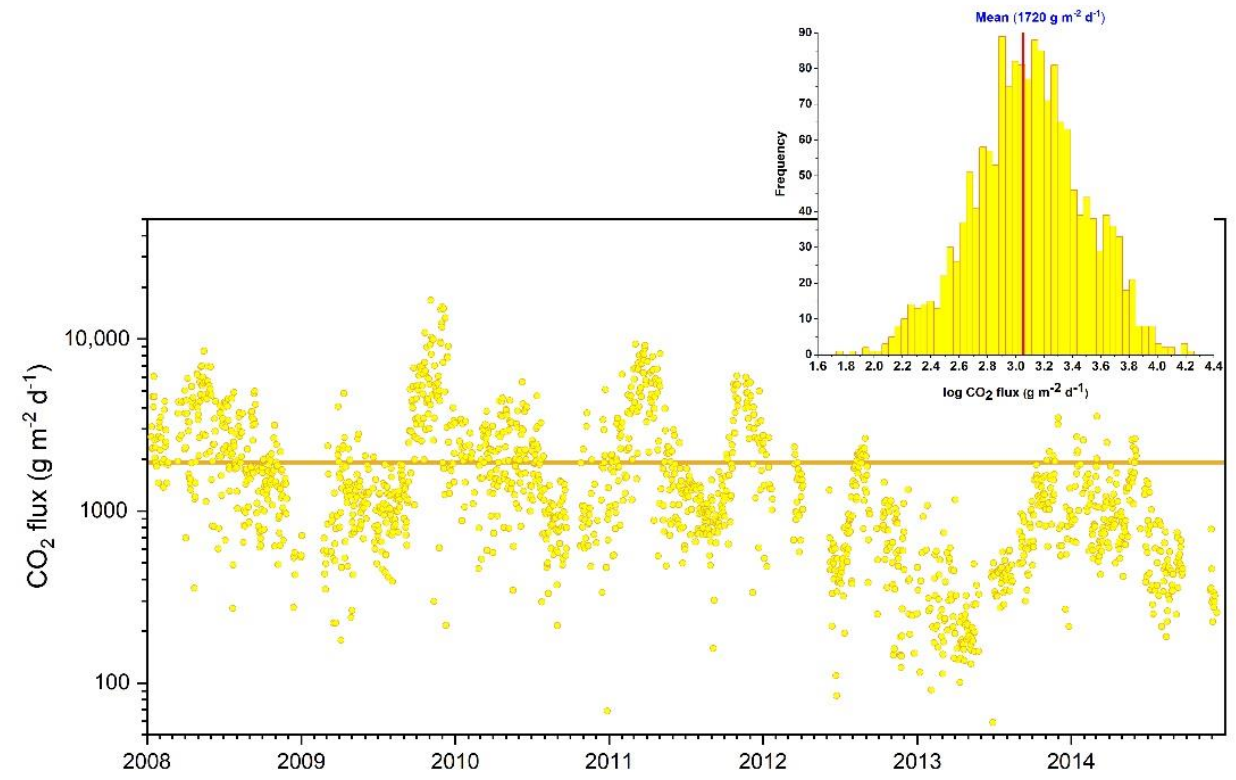

Figure 16. Daily average (24 measurements/day) of $\mathrm{CO}_{2}$ fluxes of VSCS station of the 2008-2014 period. Histogram of the $\mathrm{CO}_{2}$ fluxes data with a mean value of $1720 \mathrm{~g} \mathrm{~m}^{-2} \mathrm{~d}^{-1}$, reported on the horizontal yellow line.

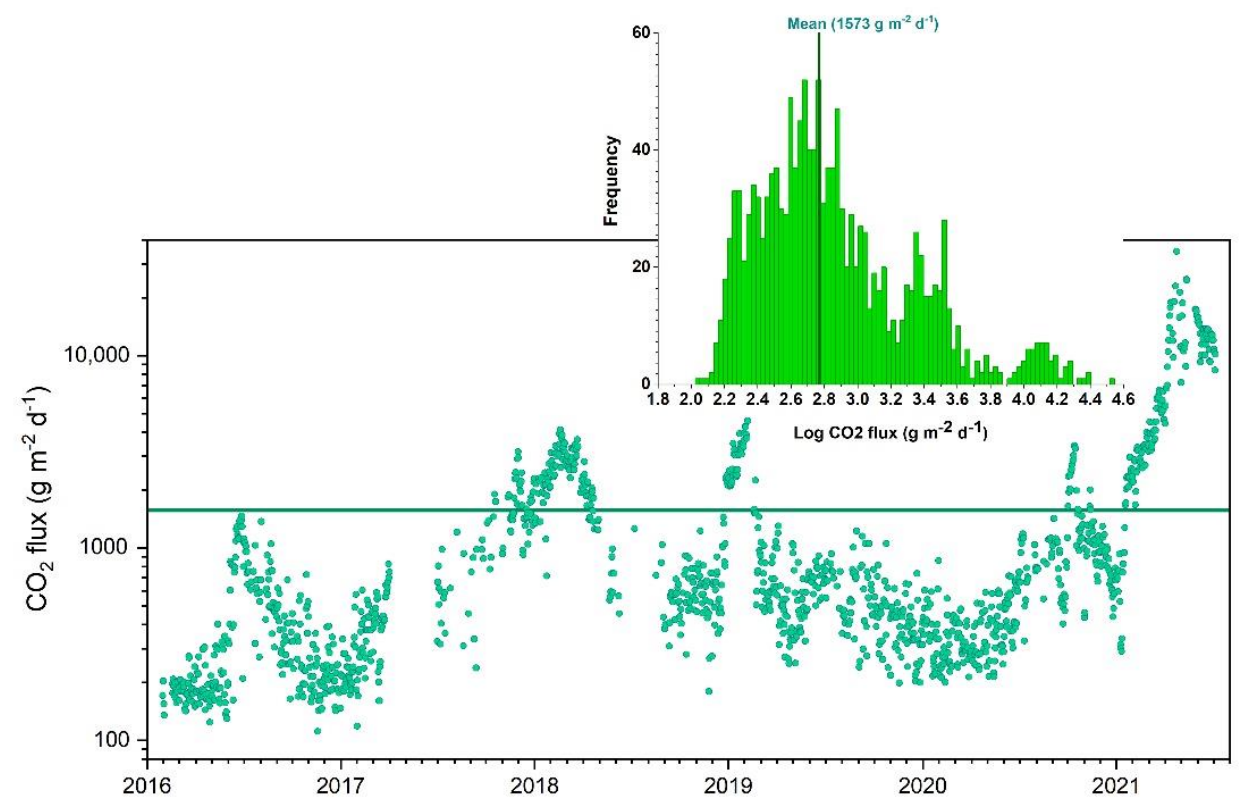

Figure 17. Daily average (24 measurements/day) of $\mathrm{CO}_{2}$ fluxes of VSCS station of the 2016-2021 period. Histogram of the $\mathrm{CO}_{2}$ fluxes data with a mean value of $1573 \mathrm{~g} \mathrm{~m}^{-2} \mathrm{~d}^{-1}$, reported on the horizontal green line. 
The cumulated probability plot, applied to the $\mathrm{CO}_{2}$ flux data, show that the 2007-2014 period is characterized by a unimodal distribution of degassing family, while the 2016-2021 period is characterized by a three-modal distribution with different degassing families respectively showing frequencies of $10 \%, 85$ and $5 \%$, with the respective mean $\mathrm{CO}_{2}$ flux values diffused from the ground of 180, 663 and $8155 \mathrm{~g} \mathrm{~m}^{-2} \mathrm{~d}^{-1}$ (Figures 14-16 and Table 4).

Table 4. Results of the partition shown in Figure 18 of the diffuse $\mathrm{CO}_{2}$ flux recorded daily at the VSCS station, based on the method of Graphical Statistical Approach proposed by [68].

\begin{tabular}{cccc}
\hline $\begin{array}{c}\text { Population } \\
\text { of } \mathrm{CO}_{2} \text { Flux }\end{array}$ & $\begin{array}{c}\text { Mean Flux of } \\
\mathbf{C O}_{2} \\
\left(\mathbf{g ~ m}^{-2} \mathbf{d}^{-1}\right)\end{array}$ & $\begin{array}{c}\mathbf{9 0 \%} \\
\text { Confidence } \\
\text { Interval } \\
\left(\mathbf{g ~ m}^{-\mathbf{2}} \mathbf{~ d}^{-\mathbf{1}}\right)\end{array}$ & $\begin{array}{c}\text { Proportion } \\
(\%)\end{array}$ \\
\hline $\mathrm{A}$ & 180 & $177-184$ & 10 \\
\hline $\mathrm{B}$ & 663 & $635-693$ & 85 \\
\hline $\mathrm{C}$ & 8155 & $7676-8726$ & 5 \\
\hline
\end{tabular}
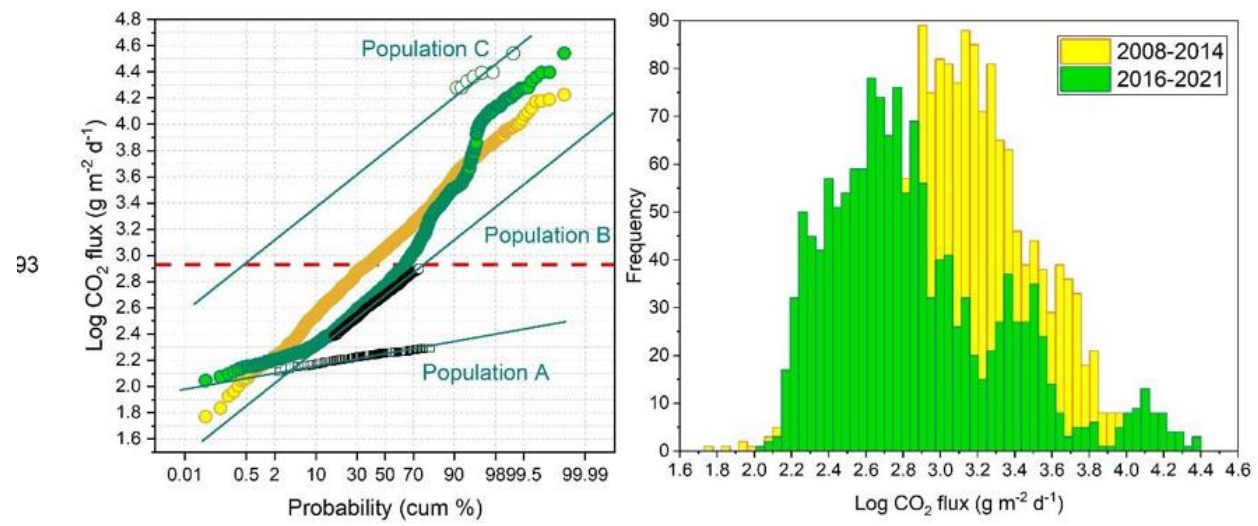

Figure 18. Partition of the diffuse $\mathrm{CO}_{2}$ flux from the ground recorded daily from the VSCS monitoring system, according to the method of Graphical Statistical Approach proposed by [68].

Figure 19a shows the strong increase, registered during 2021 on both fluxes degassing rate (daily) and $\mathrm{SO}_{2}$ fluxes in September 2021, with $3 \mathrm{t} \mathrm{d}^{-2}$ rate of $\mathrm{SO}_{2}$ increasing daily and over $100 \mathrm{t} \mathrm{d}^{-2}$ plume $\mathrm{SO}_{2}$ flux.

Figure $19 \mathrm{~b}$ shows the strong increase, registered during 2021 on both fluxes degassing rate (daily) and $\mathrm{CO}_{2}$ fluxes in September 2021, with $1000 \mathrm{~g} \mathrm{~m}^{2} \mathrm{~d}^{-2}$ rate of $\mathrm{CO}_{2}$ increasing daily and over $10,000 \mathrm{~g} \mathrm{~m}^{2} \mathrm{~d}^{-1}$ diffuse $\mathrm{CO}_{2}$ flux. However, the anomalous diffuse degassing started in June-July 2021, with a minimum rate of about $60 \mathrm{~g} \mathrm{~m}^{2} \mathrm{~d}^{-2}$ and fluxes of $3000 \mathrm{~g} \mathrm{~m}^{2} \mathrm{~d}^{-1}$. In the following period, from October to December 2021, a decreasing rate of $\mathrm{CO}_{2}$ fluxes has been recorded; even if the monthly $\mathrm{CO}_{2}$ fluxes remained around $10,000 \mathrm{~g} \mathrm{~m}^{2} \mathrm{~d}^{-1}$, that is one order of magnitude higher than the average value recorded in the last 5 years $\left(500 \mathrm{~g} \mathrm{~m}^{2} \mathrm{~d}^{-1}\right)$.

Focusing on the last year of heat flux monitoring (Figure 20), the diffuse heat flux diffused from the ground oscillated within the background range of values from April to July, but in May and October, the heat flux showed the greatest dispersion of daily values. Such great dispersions reflect the condition of an altered equilibrium in the outgassing, but only a multi-parameter correlation could confirm this hypothesis. The anomalous heat flux resulting at VSCS during May does not show a positive correlation with the other two extensive parameters discussed here $\left(\mathrm{CO}_{2}\right.$ flux diffused from soil and $\mathrm{SO}_{2}$ flux released in the volcanic plume emitted by the high-temperature fumaroles). Afterwards, the heat flux at the VSCS station began increasing in June 2021, but the strongest increasing rates were observed in September and November. The ideal condition requested for this simplified thermal monitoring system was lost for about two weeks (28 September10 October), when the conductive transfer became the minor component in the local heat 
balance and the convective transfer was undetermined. For this reason, the heat flux based only on the temperature gradient resulted in a high underestimation, temporarily interrupting the direct correlation with the general trend of the anomalous gas emissions from the volcanic system.

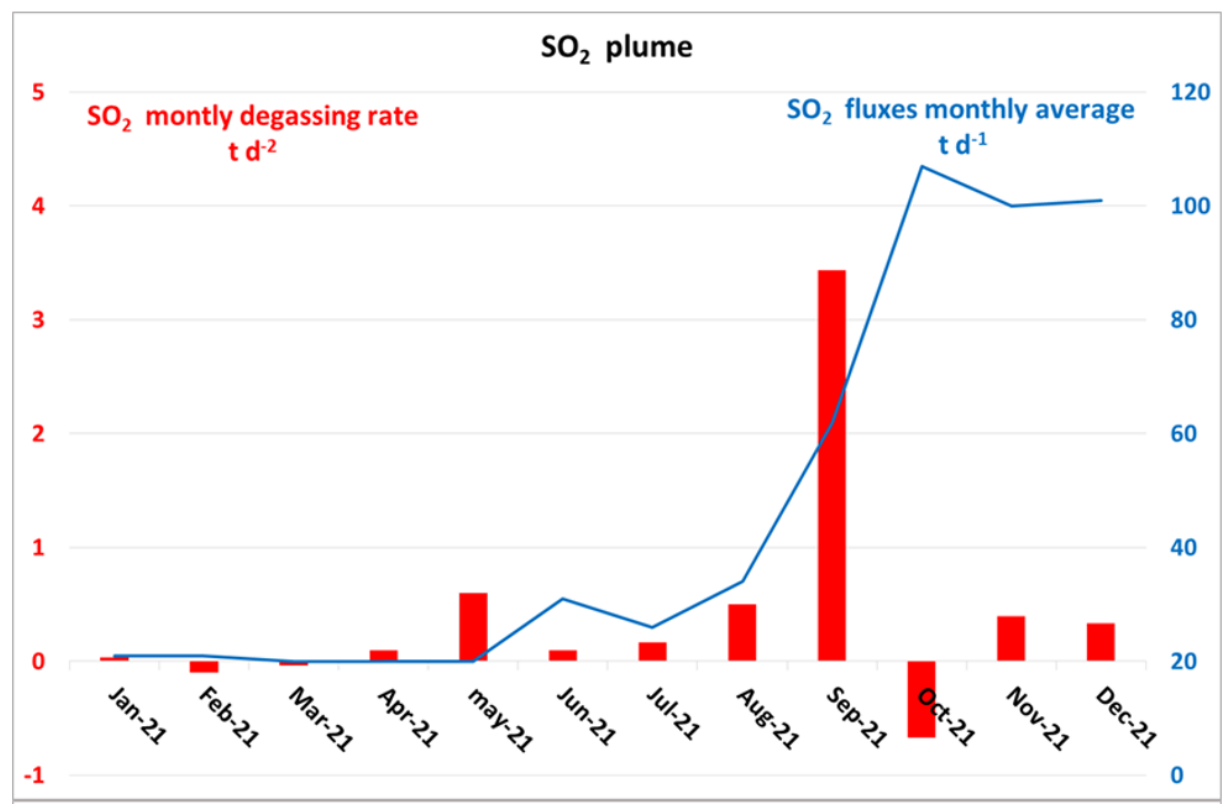

(a)

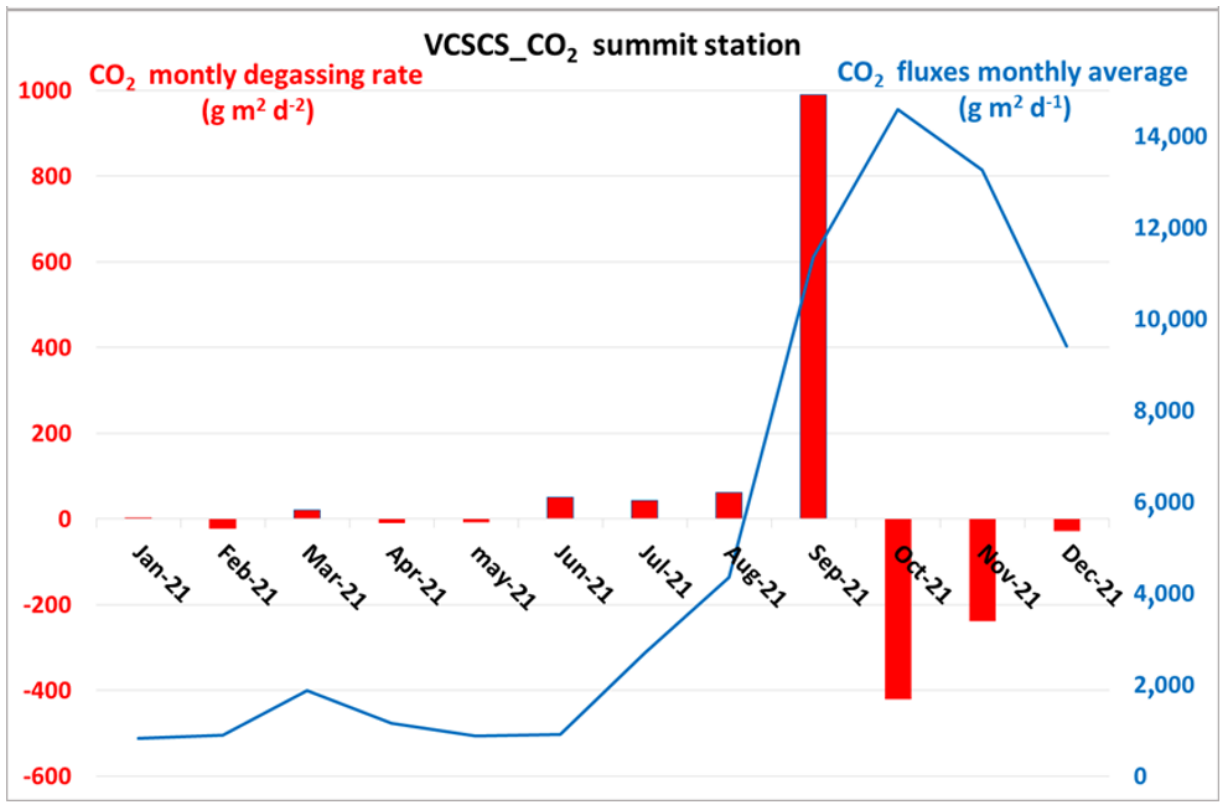

(b)

Figure 19. (a) $\mathrm{SO}_{2}$ plume degassing, monthly $\mathrm{SO}_{2}$ degassing rate $\left(\mathrm{t} \mathrm{d}^{-2}\right)$ and $\mathrm{SO}_{2}$ fluxes monthly average $\left(\mathrm{t} \mathrm{d}^{-1}\right)$ of 2021 period. Red bars indicate the increasing degassing rate; blue bars indicate the decreasing degassing rate. The brown line represents the monthly average of SO2 fluxes. (b) VCSCS summit station, monthly $\mathrm{CO}_{2}$ degassing rate and $\mathrm{CO}_{2}$ fluxes monthly average of 2021 period. Red bars indicate the increasing degassing rate; blue bars indicate the decreasing degassing rate. The brown line represents the monthly average of $\mathrm{CO}_{2}$ fluxes.

During the second half of 2021, a clear change in degassing style was recorded for the volatiles emitted by the magma in the summit area, such as the flux of diffused $\mathrm{CO}_{2}$ from the soils and the flux of the $\mathrm{SO}_{2}$ of the plume emitted by the fumarolic field. In 
particular, the volatiles released from the magma stored $2-3 \mathrm{~km}$ below the Vulcano edifice, rose towards the surface and interacted with the shallow hydrothermal system (Figure 21). During the background level of activity, groundwater receive, modulate and partially buffer, the fluids released from the magmatic bottom source produced a volatile scrubbing process that modulated the normal shallow solfataric degassing activity. This condition determined a uni-modal distribution in the degassing style, as we observed from 2007 to 2015 (Figure 15). Differently, during a geochemical crisis, the groundwaters were not able to modulate or buffer the new increased volatiles fluxes anymore. In this case, the monitoring stations showed that the heat and $\mathrm{CO}_{2}$ fluxes in the diffuse degassing areas increased over the statistical thresholds of the background, and the DOAS network revealed more than one order of magnitude increase of $\mathrm{SO}_{2}$ flux from the fumaroles field. This is what we observed during the last period, and these conditions determine a tri-modal distribution of degassing families (Figure 18).

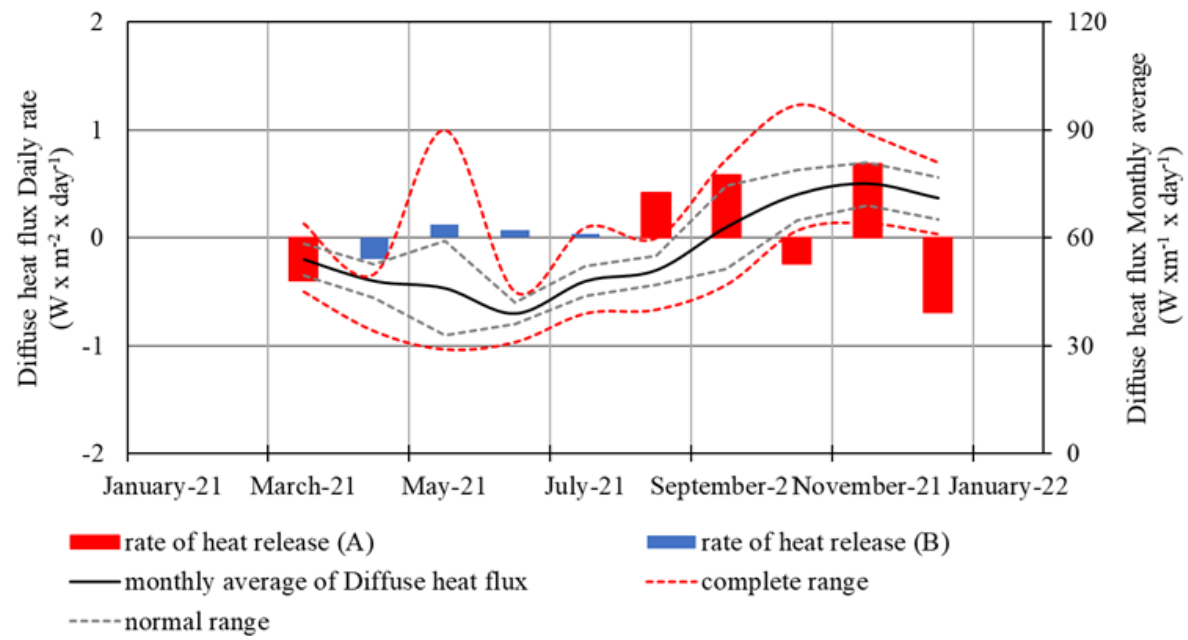

Figure 20. Time variation of diffuse heat flux from the summit station VSCS (red curve) and daily rate of heat release evaluated on a monthly base during the year 2021 (red bars for anomalous degassing average, blue bars for the background average degassing). The red border indicates the entire range of values and the grey border indicates the statistical "normal range" of values from the hourly record, resulting from a unimodal distribution around the average values. The highest values of diffuse heat fluxes occurred seldom in the months of May and much more frequently in October 2021.

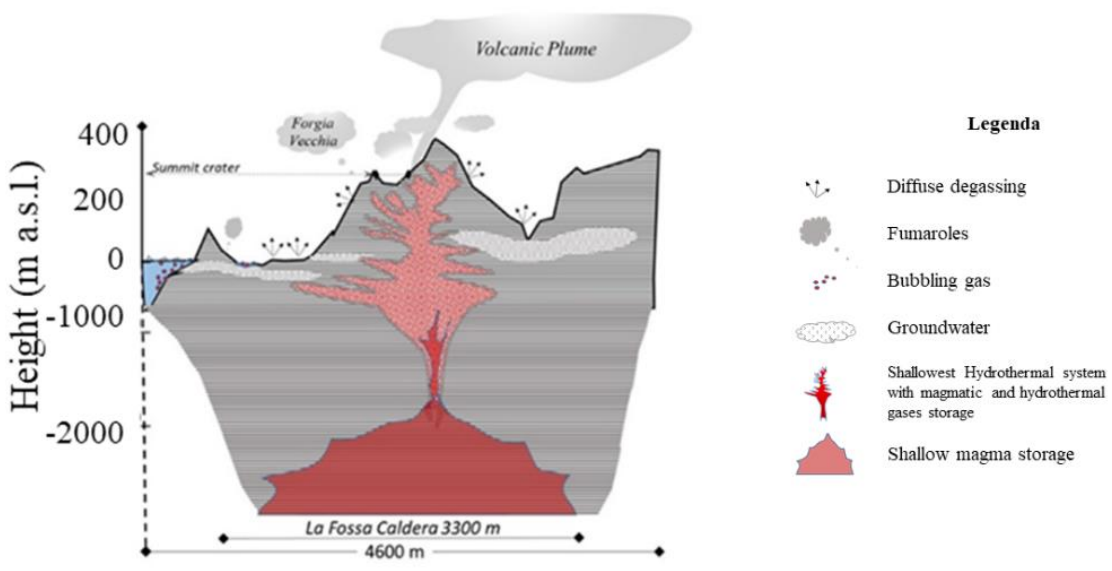

Figure 21. NW-NE profile of the Caldera La Fossa running from Mt. Lentia, Vulcano Piano. The ratio between height and length of this profile is $\mathrm{H} / \mathrm{L}=1.5$; the total length is $4.6 \mathrm{~km}$; and La Fossa Caldera occupies $3.3 \mathrm{~km}$ along this section. The schematic section shows the model of solfataric release in background condition (modified from [5,9,55] Inguaggiato et al., 2012; Federico et al., 2010; Fusillo et al., 2015). 


\section{Conclusions}

The long-term monitoring of the hydrothermal release from the summit area of the active cone of La Fossa highlighted the huge increase of energy and mass output occurring in the second half of 2021 on the Island of Vulcano. The correlation among these three different and independent geochemical parameters allowed the quantification of timing and the intensity of the actual volcanic crisis, updating the obtained results and evaluations in almost real-time. The three remotely controlled monitoring systems discussed here are tracking the evolution of exhaling activity without exposing the research units involved in the maintenance of the network to the growing gas hazard.

This geochemical monitoring method, based on the selection of a few independent variables, which are closely related to the energy and mass flux escaping from the deep magmatic system, is still sustainable, even when the severe environmental conditions in the main fumaroles area become ever more adverse and the visitors are forbidden to reach the summit zone of the active cone due to the increase of solfataric activity.

Thanks to the long-term time series of monitoring data, these authors defined the local thresholds of the background for the exhaling activity by means of simple but robust statistical evaluations based on several thousands of validated measures to show the behavior of each monitored variable: $\mathrm{SO}_{2}$ flux plume, diffuse $\mathrm{CO}_{2}$ flux and diffuse heat flux.

The monitoring station of these fluid emanations are extremely site-sensible, but the location selected here ensures correlated evidence of massive steam releases from the summit of the La Fossa cone by means of independent acquisitions by remote sensing flux evaluations in the volcanic plume, $\mathrm{CO}_{2}$ diffused flux and thermal anomalies.

The long-term data comparisons show that the simple thermal monitoring of the shallow ground is useful to track the time variation of the extensive flux of hydrothermal origin, thanks to the direct relationship between the temperature of the ground and the flow of steam and hot gas rising through the main fractures and fumarole conduits.

In conclusion, the extensive parameters indicate that the increases in mass and energy output in the summit area of the La Fossa crater began in June 2021. Then, a sharp variation starting in September 2021 brought both the $\mathrm{SO}_{2}$ flux in the plume, as well as the $\mathrm{CO}_{2}$ and the heat fluxes from the diffuse degassing zone to their respective actual absolute maximum values. In particular, we underline that the plume $\mathrm{SO}_{2}$ flux, soil $\mathrm{CO}_{2}$ fluxes from the VCSCS station and soil $\mathrm{CO}_{2}$ output, all measured with different techniques but all related to the outgassing activity, showed sharp increases in September 2021, with similar factors (e.g., 10, 20 and 16 times higher respectively) respect to their background degassing values.

After these sharp increasing fluxes, we observed from October to December a halt of the growing rate of the extensive parameter with a slight decrease, followed by a stabilization of the phenomenon on new levels, an order of magnitude higher than the background evaluated during the previous 13 years of observation. On the base of the degassing sketch model supplied so far, we strongly suggest following up this monitoring activity and comparing observable parameters (geophysical and geochemical ones) as far as possible to capture - in useful time-any variation of this state of activity.

Finally, the long-term monitoring of this volcanic system confirmed that this last crisis had been far more intense than the previous ones because it falls well over the normal oscillation of the hydrothermal system. To date, the degassing activity is still very intense, and the system seems to have reached a new equilibrium state characterized by high fluid pressures in the shallowest storage zone.

Many different processes may alter this new equilibrium condition, possibly resulting in the destabilization of this new dynamic degassing balance between the input/output of volatiles through the shallow hydrothermal systems.

Tracking the trending variation of extensive fluxes, we could follow the evolution of this active system towards different scenarios: the opening and/or reactivation of faults, corresponding an increase in surface permeability caused by seismic activity, coupled with a decrease in the deep input, could bring the pressure of the surface plumbing system back to pre-crisis values, while a new deep input of volatiles from magmatic storage, occurring 
in this new energetic steady state, could trigger the next unrest, leading to the next phreatic and/or magmatic explosive activity.

The prediction of the occurrence of a phreatic eruption and the identification of possible precursors has been a debated topic for many years. This debate has led to the identification of the actions to be adopted in order to characterize and monitor a volcanic system [75] and identify a modus operandi able to evaluate the variation of the state of volcanic activity [1,76]. The presence of a modern, multidisciplinary and efficient monitoring system is a fundamental requirement to achieve useful results for the possible prediction of paroxysmal events. The island of Vulcano possesses all these requisites and the evolution of the volcanic activity in progress will certainly provide useful information to enrich the international case history, better linking the observed geochemical variations of the hydrothermal system with changes in volcanic activity. Furthermore, it is important and desirable for the data presented in this work to be compared with the geophysical data acquired from the other monitoring networks installed on the island (accounting for seismicity, deformation, tremor, etc.) to formulate a more complete dynamic model, including the deep and shallow plumbing systems of Vulcano Island.

Author Contributions: Conceptualization, S.I. and F.V.; methodology, F.V., I.S.D., L.C., M.C. and A.M. (Andrea Mastrolia); validation, F.V., I.S.D. and L.C.; investigation, S.I.; data curation, L.C., F.V. and S.I.; writing-original draft preparation, S.I., I.S.D. and A.M. (Agnes Mazot); writing-review and editing, S.I. and I.S.D. All authors have read and agreed to the published version of the manuscript.

Funding: This research was funded by the INGV-DPCN (Italian National Institute of Geophysics and Volcanology-Italian National Department for Civil Protection) volcanic surveillance program of Vulcano island, ObFu 0304.010. Moreover, this investigation was partially funded by the TORS project in the framework of institutional INGV projects "Ricerca Libera" ObFu 9999.549; and Pianeta Dinamico Task V2, ObFu 1020.010.

Data Availability Statement: Not Applicable.

Acknowledgments: The authors wish to thank their colleagues at the Istituto Nazionale di Geofisica e Vulcanologia of Palermo for their help in acquiring and processing data and for their support in field logistics. We also thank Fawzi Dumaz for the DEM map of Vulcano Island.

Conflicts of Interest: The authors declare no conflict of interest.

\section{References}

1. Inguaggiato, S.; Diliberto, I.S.; Federico, C.; Paonita, A.; Vita, F. Review of the evolution of geochemical monitoring, networks and methodologies applied to the volcanoes of the Aeolian Arc (Italy). Earth Sci. Rev. 2018, 176, 241-276. [CrossRef]

2. Diliberto, I.S. Cyclic Behavior in the Fumaroles Output Detected by Direct Measurement of Temperature of the Ground. Eng. Proc. 2021, 5, 47. [CrossRef]

3. Camarda, M.; De Gregorio, S.; Capasso, G.; Di Martino, R.M.R.; Gurrieri, S.; Prano, V. The monitoring of natural soil CO 2 emissions: Issues and perspectives. Earth Sci. Rev. 2019, 198, 102928. [CrossRef]

4. Capasso, G.; Favara, R.; Inguaggiato, S. Chemical features and isotopic composition of gaseous manifestations on Vulcano Island, Aeolian Islands, Italy: An interpretative model of fluid circulation. Geochim. Cosmochim. Acta 1997, 61, 3425-3440. [CrossRef]

5. Inguaggiato, S.; Calderone, L.; Inguaggiato, C.; Mazot, A.; Morici, S.; Vita, F. Long-time variation of soil $\mathrm{CO}_{2}$ fluxes at summit crater of Vulcano (Italy). Bull. Volcanol. 2012, 74, 1859-1863. [CrossRef]

6. Inguaggiato, S.; Mazot, A.; Diliberto, I.S.; Inguaggiato, C.; Madonia, P.; Rouwet, D.; Vita, F. Total CO 2 output from Vulcano island (Aeolian Islands, Italy). Geochem. Geophys. Geosys. 2012, 13, 1-19. [CrossRef]

7. Vita, F.; Inguaggiato, S.; Bobrowski, N.; Calderone, L.; Galle, B.; Parello, F. Continuous $\mathrm{SO}_{2}$ flux measurements for Vulcano Island, Italy. Ann. Geophys. 2012, 55, 2. [CrossRef]

8. Paonita, A.; Federico, C.; Bonfanti, P.; Capasso, G.; Inguaggiato, S.; Italiano, F.; Madonia, P.; Pecoraino, G.; Sortino, F. The episodic and abrupt geochemical changes at La Fossa fumaroles (Vulcano Island, Italy) and related constraints on the dynamics, structure, and compositions of the magmatic system. Geochim. Cosmochim. Acta. 2013, 120, 158-178. [CrossRef]

9. Federico, C.; Capasso, G.; Paonita, A.; Favara, R. Effects of steam-heating processes on a stratified volcanic aquifer: Stable isotopes and dissolved gases in thermal waters of Vulcano Island (Aeolian archipelago). J. Volcanol. Geotherm. Res. 2010, 192, 178-190. [CrossRef]

10. Aiuppa, A.; Burton, M.; Mure, F.; Inguaggiato, S. Intercomparison of volcanic gas monitoring methodologies performed on Vulcano Island, Italy. Geophys. Res. Lett. 2004, 31, L02610. [CrossRef] 
11. Aiuppa, A.; Inguaggiato, S.; McGonigle, A.J.S.; O’Dwyer, M.; Oppenheimer, C.; Padgett, M.J.; Rouwet, D.; Valenza, M. H2S fluxes from Mt. Etna, Stromboli, and Vulcano (Italy) and implications for the sulfur budget at volcanoes. Geochim. Cosmochim. Acta 2004, 69, 1861-1871. [CrossRef]

12. O'Dwyer, M.; Padgett, M.J.; McGonigle, A.J.S.; Oppenheimer, C.; Inguaggiato, S. Real-time measurement of volcanic $\mathrm{H}_{2} \mathrm{~S}$ and $\mathrm{SO}_{2}$ concentrations by UV spectroscopy. Geopys. Res. Lett. 2003, 30, 1652. [CrossRef]

13. Carapezza, M.; Nuccio, P.M.; Valenza, M. Genesis and evolution of the fumaroles of vulcano (Aeolian Islands, Italy): A geochemical model. Bull. Volcanol. 1981, 44, 547-563. [CrossRef]

14. Barberi, F.; Neri, G.; Valenza, M.; Villari, L. 1987-1990 unrest at Vulcano. Acta Vulcanol. 1991, 1, $95-106$.

15. Capasso, G.; Inguaggiato, S.; Nuccio, P.M.; Pecoraino, G.; Sortino, F. Compositional evolution of the fumarolic gases emitted at the crater of Vulcano during 1987-1993. In Proceedings of the Independent Publishers Group World Organization of Volcano Observatories Meeting, Guadalupe, CA, USA, 13-17 December 1993; pp. 109-126.

16. Cioni, R.; D'Amore, F. A genetic model for the crater fumaroles of Vulcano island (Sicily, Italy). Geothermics 1984, 13, 375-384 [CrossRef]

17. Chiodini, G.; Cioni, R.; Falsaperla, S.; Guidi, M.; Marini, L.; Montalto, A. Geochemical and seismological investigations at Vulcano (Aeolian Islands) during 1978-1989. J. Geophys. Res. 1992, 97, 11025-11032. [CrossRef]

18. Badalamenti, B.; Chiodini, G.; Cioni, R.; Favara, R.; Francofonte, S.; Gurrieri, S.; Hauser, S.; Inguaggiato, S.; Italiano, F.; Magro, G.; et al. Special field workshop at Vulcano (Aeolian Islands) during summer 1988. Geochemical results. Acta Vulcanol. 1991, 1, 223-227.

19. Capasso, G.; Favara, R.; Francofonte, S.; Inguaggiato, S. Chemical and isotopic variations in fumarolic discharge and thermal waters at Vulcano Island (Aeolian Island, Italy) during 1996: Evidence of resumed volcanic activity. J. Volcanol. Geotherm. Res. 1999, 88, 167-175. [CrossRef]

20. Diliberto, I.S. Long-term monitoring on a closed-conduit volcano: A 25-year long time-series of temperatures recorded at La Fossa cone (Vulcano Island). J. Volcanol. Geotherm. Res. 2017, 346, 151-160. [CrossRef]

21. Cannata, A.; Diliberto, I.S.; Alparone, S.; Gambino, S.; Gresta, S.; Liotta, M.; Madonia, P.; Milluzzo, V.; Aliotta, M.; Montalto, P. Multiparametric Approach in Investigating Volcano-Hydrothermal Systems: The Case Study of Vulcano (Aeolian Islands, Italy). Pure Appl. Geophys. 2012, 169, 167-182. [CrossRef]

22. Capasso, G.; Federico, C.; Madonia, P.; Paonita, A. Response of the shallow aquifer of the volcano-hydrothermal system during the recent crises at Vulcano Island (Aeolian Archipelago, Italy). J. Volcanol. Geotherm. Res. 2014, 273, 70-80. [CrossRef]

23. Girona, T.; Costa, F.; Newhall, C.; Taisne, B. On depressurization of volcanic magma reservoirs by passive degassing. J. Geophys. Res. Solid Earth 2014, 119, 8667-8687. [CrossRef]

24. Maldonado, L.F.M.; Inguaggiato, S.; Jaramillo, M.T.; Garzon Valencia, G.; Mazot, A. Volatiles and energy released by Puracè volcano. Bull. Volcanol. 2017, 79, 84. [CrossRef]

25. Inguaggiato, S.; Vita, F.; Cangemi, M.; Mazot, A.; Sollami, A.; Calderone, L.; Morici, S.; Jacome Paz, M.P. Stromboli volcanic activity variations inferred by fluids geochemistry observations: Sixteen years of continuous soil $\mathrm{CO}_{2}$ fluxes monitoring (2000-2015) Chem. Geol. 2017, 469, 69-84. [CrossRef]

26. Inguaggiato, S.; Cardellini, C.; Taran, Y.; Kalacheva, E. The $\mathrm{CO}_{2}$ flux from hydrothermal systems of the Karymsky volcanic Centre, Kamchatka. J. Volcanol. Geotherm. Res. 2017, 346, 1-9. [CrossRef]

27. Inguaggiato, S.; Vita, F.; Rouwet, D.; Bobrowski, N.; Morici, S.; Sollami, A. Geochemical evidence of the renewal of volcanic activity inferred from $\mathrm{CO}_{2}$ soil and $\mathrm{SO}_{2}$ plume fluxes: The 2007 Stromboli eruption (Italy). Bull. Volcanol. 2011, 73, 443-456. [CrossRef]

28. Inguaggiato, S.; Vita, F.; Cangemi, M.; Calderone, L. Increasing Summit Degassing at the Stromboli Volcano and Relationships with Volcanic Activity (2016-2018). Geosciences 2019, 9, 176. [CrossRef]

29. Inguaggiato, S.; Vita, F.; Cangemi, M.; Calderone, L. Changes in $\mathrm{CO}_{2}$ Soil Degassing Style as a Possible Precursor to Volcanic Activity: The 2019 Case of Stromboli Paroxysmal Eruptions. Appl. Sci. 2020, 10, 4757. [CrossRef]

30. Inguaggiato, S.; Vita, F.; Cangemi, M.; Inguaggiato, C.; Calderone, L. The Monitoring of $\mathrm{CO}_{2}$ Soil Degassing as Indicator of Increasing Volcanic Activity: The Paroxysmal Activity at Stromboli Volcano in 2019-2021. Geosciences 2021, 11, 169. [CrossRef]

31. Jacome Paz, M.P.; Taran, Y.; Inguaggiato, S.; Collard, N. CO flux and chemistry of El Chichon crater lake (Mexico) in the period 2013-2015: Evidence for the enhanced volcano activity. Geophys. Res. Lett. 2016, 43, 127-134. [CrossRef]

32. Diliberto, I.S.; Gurrieri, S.; Valenza, M. Relationships between diffuse $\mathrm{CO}_{2}$ emissions and volcanic activity on the island of Vulcano (Aeolian Islands, Italy) during the period 1984-1994. Bull. Volcanol. 2002, 64, 219-228. [CrossRef]

33. Granieri, D.; Carapezza, M.L.; Chiodini, G.; Avino, R.; Caliro, S.; Ranaldi, M.; Tarchini, L. Correlated increase in $\mathrm{CO}_{2}$ fumarolic content and diffuse emission from La Fossa crater (Vulcano, Italy): Evidence of volcanic unrest or increasing gas release from a stationary deep magma body? Geophys. Res. Lett. 2006, 33, L13316. [CrossRef]

34. Carapezza, M.L.; Granieri, D. $\mathrm{CO}_{2}$ soil flux at Vulcano (Italy): Comparison of active and passive methods and application to the identification of actively degassing structure. Appl. Geochem. 2004, 19, 73-88. [CrossRef]

35. Chiodini, G.; Granieri, D.; Avino, R.; Caliro, S.; Costa, A.; Werner, C. Carbon dioxide diffuse degassing and estimation of heat release from volcanic and hydrothermal systems. J. Geophys. Res. 2005, 110, B08204. [CrossRef]

36. Aubert, M.; Diliberto, S.; Finizola, A.; Chebli, Y. Double origin of hydrothermal convective flux variations in the Fossa of Vulcano (Italy). Bull. Volcanol. 2008, 70, 743-751. [CrossRef] 
37. Aubert, M.; Alparone, S. Variation d'origine sismique du flux de chaleur convectif dans La Fossa de Vulcano (Italie). Comptes Rendus L'academie Sci. Ser. II A Earth Planet Sci. 2000, 330, 603-610. [CrossRef]

38. Diliberto, I.S. Long-term variations of fumaroles temperatures on Vulcano Island (Italy). Ann. Geophys. 2011, 54, 2011. [CrossRef]

39. Diliberto, I.S. Time series analysis of high temperature fumaroles monitored on the island of Vulcano (Aeolian Archipelago, italy). J. Volcanol. Geotherm. Res. 2013, 264, 150-163. [CrossRef]

40. Ruch, J.; Vezzoli, L.; De Rosa, R.; Di Lorenzo, R.; Acocella, V. Magmatic control along a strike—Slip volcanic arc: The central Aeolian arc (Italy). Tectonics 2016, 35, 407-424. [CrossRef]

41. Peccerillo, A.; De Astis, G.; Faraone, D.; Forni, F.; Frezzotti, M.L. Compositional variations of magmas in the Aeolian arc: Implications for petrogenesis and geodynamics. Geol. Soc. Lond. Mem. 2013, 37, 491-510. [CrossRef]

42. Peccerillo, A.; Frezzotti, M.L.; De Astis, G.; Ventura, G. Modeling the magma plumbing system of Vulcano (Aeolian Islands, Italy) by integrated fluid-inclusion geobarometry, petrology, and geophysics. Geology 2006, 34, 17-20. [CrossRef]

43. De Astis, G.; Lucchi, F.; Dellino, P.; La Volpe, L.; Tranne, C.A.; Frezzotti, M.L.; Peccerillo, A. Geology, volcanic history and petrology of Vulcano (central Aeolian archipelago). Geol. Soc. Lond. Mem. 2013, 37, 281-349. [CrossRef]

44. Neri, G.; Barberi, B.; Oliva, G.; Orecchio, B. Spatial variation of seismogenic stress orientations in Sicily, south Italy. Phys. Earth Planet. Inter. 2005, 148, 175-191. [CrossRef]

45. Goes, S.; Giardini, D.; Jenny, S.; Hollenstein, C.; Kahle, H.-G.; Geiger, A. A recent reorganization in the south-central Mediterranean Earth Planet. Sci. Lett. 2004, 226, 335-345. [CrossRef]

46. Billi, A.; Barberi, G.; Faccenna, C.; Neri, G.; Pepe, F.; Sulli, A. Tectonics and seismicity of the Tindary Fault System, southern Italy: Crustal deformations at the transition between ongoing contractional and extensional domains located above the edge of a subducting slab. Tectonics 2006, 25, TC2006. [CrossRef]

47. D'Agostino, N.; Selvaggi, G. Crustal motion along the Eurasia-Nubia plate boundary in the Calabrian Arc and Sicily and active extension in the Messina Straits from GPS measurements. J. Geophys. Res. 2004, 109, B11402. [CrossRef]

48. Keller, J. The island of Vulcano. Rend. Soc. Italy Miner. Petr. 1980, 36, 369-414.

49. Lanza, R.; Zanella, E. Paleomagnetic secular variation at Vulcano (Aeolian islands) during the last 135 kyr. Earth Planet. Sci. Lett. 2003, 213, 321-336. [CrossRef]

50. Gioncada, A.; Sbrana, A. “La Fossa Caldera”, Vulcano: Inferences from deep drillings. Acta Vulcanol. 1991, 1, 115-126.

51. Frazzetta, G.; Gillot, P.Y.; La Volpe, L.; Sheridan, M.F. Volcanic hazards at Fossa of Vulcano: Data from the last 6000 years. Bull. Volcanol. 1984, 47, 105-124. [CrossRef]

52. Ventura, G.; Vilardo, G.; Milano, G.; Pino, N.A. Relationships among crustal structure volcanism and strike-slip tectonics in the Lipari-Vulcano volcanic complex (Aeolian Islands, Southern Tyrrhenian Sea, Italy). Phys. Earth Planet Inter. 1999, 116, 31-52. [CrossRef]

53. Fusillo, R.; Di Traglia, F.; Gioncada, A.; Pistolesi, M.; Wallace, P.J.; Rosi, M. Deciphering post-caldera volcanism: Insight into the Vulcanello (Island of Vulcano, Southern Italy) eruptive activity based on geological and petrological constraints. Bull. Volcanol. 2015, 77, 1-23. [CrossRef]

54. Platt, U.; Stutz, J. Differential Optical Absorption Spectroscopy Principles and Applications; Physics of Earth and Space Environments; Springer: Berlin/Heidelberg, Germany, 2008; p. 597. ISBN 978-3-540-75776-4.

55. Platt, U. Differential optical absorption spectroscopy (DOAS). In Air Monitoring by Spectroscopic Techniques; Chemical Analysis Series; Sigrist, M.W., Ed.; John Wiley \& Sons Inc.: Hoboken, NJ, USA, 1994; Volume 127, pp. 27-83.

56. Edmonds, M.; Herd, H.; Galle, B.; Oppenheimer, C. Automated, high time-resolution measurements of $\mathrm{SO}_{2}$ flux at Soufriere Hills Volcano, Montserrat. West Indies Bull. Volcanol. 2003, 65, 578-586. [CrossRef]

57. Kern, C.; Masias, P.; Apaza, F.; Reath, K.A.; Platt, U. Remote measurement of high preeruptive water vapor emissions at Sabancaya volcano by passive differential optical absorption spectroscopy. J. Geophys. Res. Solid Earth 2017, 122, 3540-3564. [CrossRef]

58. Vita, F.; Kern, C.; Inguaggiato, S. Development of a portable active long-path differential optical absorption spectroscopy system for volcanic gas measurements. J. Sens. Sens. Syst. 2014, 3, 355-367. [CrossRef]

59. Galle, B.; Johansson, M.; Rivera, C.; Zhang, Y.; Kihlman, M.; Kern, C.; Lehmann, T.; Platt, U.; Arellano, S.; Hidalgo, S. Network for Observation of Volcanic and Atmospheric Change (NOVAC): A global network for volcanic gas monitoring -Network layout and instrument description. J. Geophys. Res. 2010, 115, D05304. [CrossRef]

60. Arellano, S.; Galle, B.; Apaza, F.; Avard, G.; Barrington, C.; Bobrowski, N.; Bucarey, C.; Burbano, V.; Burton, M.; Chacon, Z.; et al. Synoptic analysis of a decade of daily measurements of $\mathrm{SO}_{2}$ emission in the troposphere from volcanoes of the global ground-based Network for Observation of Volcanic and Atmospheric Change. Earth Syst. Sci. Data 2021, 13, 1167-1188. [CrossRef]

61. Vita, F.; Arellano, S.; Inguaggiato, S.; Galle, B. $\mathrm{SO}_{2}$ Flux of-VULCANO-Volcano from the NOVAC Data-Base, [Data Set], v.001, The NOVAC Database 2020. Available online: https:/ / doi.org/10.17196/novac.vulcano.001 (accessed on 30 November 2021). [CrossRef]

62. Galle, B.; Delgado, H.; Garzon, G.; Vogel, L.; Platt, U. NOVAC Project Final Report, EU-FP6; Chalmers University of Technology: Gothenburg, Sweden, 2011; p. 100.

63. IUPAC. Compendium of Chemical Terminology, 2nd ed.; The "Gold, Book"; McNaught, A.D., Wilkinson, A., Eds.; Blackwell Scientific Publications: Oxford, UK, 1997; Online version (2019-) created by Chalk, S.J.; ISBN 0-9678550-9-8. [CrossRef]

64. Platt, U.; Perner, D. Measurements of Atmospheric Trace Gases by Long Path Differential UV/Visible Absorption Spectroscopy. In Optical and Laser Remote Sensing; Killinger, D.A., Mooradien, A., Eds.; Springer Verlag: New York, NY, USA, 1983 ; pp. 95-105. 
65. Johansson, M. NOVACProject/NovacPPP: NovacPPP (Post Processing Program); Version 2.0.0; Zenodo: Geneve, Switzerland, 2021. [CrossRef]

66. Johansson, M.; Galle, B.; Zhang, Y.; Rivera, C. The dual-beam mini-DOAS technique-measurements of volcanic gas emission, plume height and plume speed with a single instrument. Bull. Volcanol. 2009, 71, 747-751. [CrossRef]

67. Chiodini, G.; Cioni, R.; Guidi, M.; Raco, B.; Marini, L. Soil $\mathrm{CO}_{2}$ flux measurements in volcanic and geothermal areas. Appl. Geochem. 1998, 13, 543-552. [CrossRef]

68. Sinclair, A.J. Selection of threshold values in geochemical data using probability graphs. J. Geochem. Explor. 1974, 3, 129-149. [CrossRef]

69. Deutsch, C.; Journel, A. GSLIB: Geostatistical Software and User's Guide, 2nd ed.; Oxford University Press: New York, NY, USA, 1998; 369p.

70. Aubert, M. Practical evaluation of steady heat discharge from dormant active volcanoes: Case study of Vulcarolo fissure (Mount Etna, Italy). J. Volcanol. Geotherm. Res. 1999, 92, 413-429. [CrossRef]

71. Aubert, M.; Alparone, S. Hydrothermal convective flux variation related to a seismo-tectonic crisis in the Fossa of Vulcano (Italy). CR Geosci. 2000, 330, 603-610.

72. Gaudin, D.; Ricci, T.; Finizola, A.; Delcher, E.; Alparone, S.; Barde-Cabusson, S.; Brothelande, E.; Di Gangi, F.; Gambino, S.; Inguaggiato, S.; et al. Heat flux-based strategies for the thermal monitoring of sub-fumarolic areas: Examples from Vulcano and La Soufriere de Guadeloupe. J. Volcanol. Geotherm. Res. 2017, 343, 122-134. [CrossRef]

73. Diliberto, I.S.; Gagliano Candela, E.; Morici, S.; Pecoraino, G.; Bellomo, S.; Bitetto, M.; Longo, M. Changes in heat release by hydrothermal circulation monitored during an eruptive cycle on Mount Etna (Italy). Bull. Volcanol. 2018, 80, 4. [CrossRef]

74. David, M. Geostatistical Ore Reserve Estimation; Developments in Geomathematics; Elsevier: New York, NY, USA, 1977; Volume 2,363p.

75. Barberi, F.; Bertagnini, A.; Landi, P.; Principe, C. A review on phreatic eruptions and their precursors. J. Volcanol. Geotherm. Res. 1992, 52, 231-246. [CrossRef]

76. Selva, J.; Bonadonna, C.; Branca, S.; De Astis, G.; Gambino, S.; Paonita, A.; Ricciardi, A. Multiple hazards and paths to eruptions: A review of the volcanic system of Vulcano (Aeolian Islands, Italy). Earth Sci. Rev. 2020, 207, 103186. [CrossRef] 